\title{
Wine and innovation
}

Consumer acceptance of new grape varieties and wine packaging

Dissertation to attain

the doctoral degree (Dr. rer. pol.)

of the Faculty of Agricultural Sciences

Georg-August-Universität Göttingen

Submitted by

Lucas Nesselhauf

born on 31 March 1988 in Bad Säckingen

Göttingen, September 2018 
1. Referee: Prof. Dr. Ludwig Theuvsen

2. Referee: Prof. Dr. Ruth Fleuchaus

Date of oral examination: 29 October 2018 
Standing on the shoulders of giants.

Bernard de Chartres 
Information and involvement:

The influence on the acceptance of innovative wine packaging 12

What about the environment? A choice-based conjoint study about wine. 30

The role of environmental information for wine innovation adoption The case of fungus resistant grape varieties .55

Conclusions and outlook 73

Publications 81

Declaration. 83

Curriculum Vitae 84

Acknowledgement | Danksagung .... 85 


\section{Introduction}

Wine is deeply embedded in the European culture and wine growing has a long tradition in Europe (Charters, 2006). Europe's significance in the wine world becomes obvious from both production and consumption figures. Around $60 \%$ of the world's wine is produced in Europe, and about $50 \%$ of the world's wine is consumed in Europe (Deutsches Weininstitut, 2017). In Germany, the average yearly wine production reaches the total of nine million hectolitre, yet, the Germans consume more than 20 million hectolitre. This makes the German wine market particularly interesting for other wine producing countries. The imports from Italy, France and Spain add up to almost $77 \%$ of all imports to Germany (11.1 million hectolitre of 14.5 million hectolitre) (Deutsches Weininstitut, 2017). While Germany exports around 3.6 million hectolitre per year (1 million hectolitre German wine), in general, Germany imports more wine than any other country (Deutsches Weininstitut, 2017; International Organisation of Vine and Wine, 2016).

The German wine market is highly competitive, partly because of the high amount of imports and partly due to the major role of discounters in the retail market. In 2017, $79 \%$ of the wine were sold through the food retailing industry in Germany. In that year, the average price for wines sold in supermarkets and discounters was 2.19 Euro per bottle (0.75L) (GfK, 2018). The prices for red wines are slightly higher with an average of 2.38 Euro. White wines and rosé wines have average prices of 2.02 Euro and 1.99 Euro, respectively. Taking a look at the prices separated by their country of origin, the prices for wines from the New World, i.e. nonEuropean wine producing countries, have an average price of 2.62 Euro per bottle. Italian, Spanish, French and German wines have similar prices in the range from 2.18 Euro to 2.36 Euro per bottle. In other distribution channels, such as wine shops and cellar door sales, the prices cannot be determined due to a lack of data. The importance of these distribution channels, however, decreases more and more. The wine shops sell around $3 \%$ of the wine and $8 \%$ of the wine is sold directly to consumers from the cellar door (GfK, 2018). The tense market situation in Germany forces wine growers to reduce costs as much as possible, find their niches, or stand out of the masses in any possible way to be profitable. 
Apart from the highly competitive market environment in Germany, wine growers face additional challenges, such as the climate change. The increasing temperatures during the growing season influence the wine production and the wine quality in various ways (Ashenfelter and Storchmann, 2016; Schultz, 2016). For example, in the Mosel Valley, where Riesling is the predominant grape variety, the increasing temperatures alter the ripening and the flavour of the wine (Schultz, 2016). The familiar flavours of specific regions are likely to change, therefore, either the consumers have to adapt to the new flavours or wine growers have to adapt their grape varieties to the new situation. Particularly, the harvest dates are used to determine the influence of the climate change on the wine production. In the 1930s, the harvest dates for a vineyard in Burgundy were around the $10^{\text {th }}$ October. At the beginning of the $21^{\text {st }}$ century, the dates are closer to the $20^{\text {th }}$ September (Adelsheim et al., 2016). And the trend continues: In 2018, the harvest started on the $6^{\text {th }}$ August in Germany. Compared to the average of the last 30 years, the harvest starts around three weeks earlier (Köppe, 2018).

Furthermore, warmer weather can also foster fungal diseases and pests such as the spottedwing drosophila (Ashenfelter and Storchmann, 2016; Kriener, 2014). In 2016, the German wine growers, particularly the organic wine growers, struggled with the weather conditions and the resulting fungal disease pressure (Bojanowski, 2016). Downy mildew, the fungal disease that caused the struggles in 2016, can be contained with fungicides. In 2016, however, the continuous rain impeded the application of fungicides. Organic wine growers faced further problems. Due to the organic regulations, the use of synthetic fungicides is prohibited; organic wine growers may only use copper-based fungicides. These copper-based fungicides did not suffice to contain the downy mildew completely in 2016. Furthermore, copper-based fungicides can lead to an accumulation of copper in soil and a leakage of copper into water sources (Mackie et al., 2012). Undeniably, the climate change demands a fundamental rethinking about adequate production methods in the wine industry.

A possibility to meet the challenges of the highly competitive wine market in Germany and challenges in the external environment such as climate change is the adoption of innovations. This dissertation looks at two examples of innovations. First, packaging innovations that open up new possibilities to differentiate the products from other products on the market, and second, fungus resistant grape varieties that tackle the problem of the abundant use of fungicides are analysed.

Packaging obviously serves one main purpose: the protection of the product. However, beyond this key purpose, packaging functions as well as ‘silent salesman' (Sara, 1990). The packaging is the last advocate for the product (Gómez et al., 2015; McDaniel and Baker, 1977). While consumers browse through the endless shelves of supermarkets, a packaging that stands out of the masses will make a difference (Rundh, 2009; Sara, 1990). Since the food and beverage sector is highly competitive and many similar products stand next to each other, the packaging is used as a marketing instrument (Rundh, 2016; Sara, 1990). A new 
packaging attracts attention. However, a packaging that deviates too much from the familiar packaging thwarts the connection between the new packaging to the old one. Hence, the positive brand recognition will be lost due to the new packaging (Schoormans and Robben, 1997). Therefore, the consumers' past experiences and the expectations need to be considered when designing a new packaging or choosing the optimal container for a product (Nancarrow et al., 1998). Furthermore, the convenience and practicability of a packaging can influence the quality perception, and therefore, also the likelihood to purchase these products (McDaniel and Baker, 1977; Rigaux-Bricmont, 1982; Rundh, 2016; Silayoi and Speece, 2007).

Wine is an experience good, meaning that the quality of the product cannot be determined prior to the consumption (Viot, 2012). Therefore, consumers rely particularly on the extrinsic cues of the product. The packaging is one part of these extrinsic cues. Hence, the packaging is especially important for the wine sector. Studies show that parts of the packaging, such as the label or the type of closure, influence the quality expectations and even the quality perceptions after the consumption (Atkin et al., 2006; Atkin and Newton, 2012; Barber and Almanza, 2006; Celhay and Passebois, 2011; Lopes et al., 2016; Marin and Durham, 2007; Sherman and Tuten, 2011; Veale, 2008). Therefore, a special wine packaging can serve as a tool to differentiate one product from the masses. Good examples for a differentiation approach of a wine based on the packaging are 'StackWine' and the 'Grüne Weinbox' (green wine box). 'StackWine' uses a portable and stylish single serving packaging that is supposed to attract young people. The packaging is designed for festivals, picnics, and other outdoor situations (see www.drinkstack.com). The 'Grüne Weinbox' appeals to environmentally aware consumers (see www.gruene-weinbox.de). The box is a bag-in-box with a volume of 3 litres. The company focuses on the environmental benefits of the bag-in-box in combination with the convenience and the lower production costs. Additionally, the wine sold in the 'Grüne Weinbox' is solely produced organically. In this case, the packaging matches the actual product to build a cohesive differentiation based on a smaller ecological footprint in the market.

Fungus resistant grape varieties (FRGVs) are an innovation in the wine market on the level of the ingredients. These grape varieties have one main advantage over the traditional varieties: the resistance against the fungal diseases powdery and downy mildew of grapevine. FRGVs are crossbreeds of the European vitis vinifera and American or Asian varieties (Töpfer et al., 2011). The vitis vinifera have highly appreciated sensory qualities of the traditional European grape varieties. However, the fungal diseases force European wine growers to protect the vitis vinifera grapevines with fungicides. The American and Asian varieties are resistant against the fungal diseases. Therefore, breeders combine the sensory qualities of vitis vinifera varieties with the resistances of the American and Asian varieties. As a result of this combination, the fungus resistant grape vines can be grown with a significantly lower use of fungicides. Due to the reduced applications of fungicides, the soil compression in the vineyards as well as the carbon emissions can be decreased. Apart from the environmental 
benefits, growing FRGVs reduces production costs because of the decrease in necessary labour and resources. The research for new, resistant grape varieties started at the beginning of the $20^{\text {th }}$ century. Since the middle of the 1990s, FRGVs with promising qualities are allowed in Germany. For a comprehensive overview of the history and the advantages of FRGVs, see Basler and Scherz (2011) and Pedneault and Provost (2016).

Despite the FRGVs' advantages for wine growers, less than $3 \%$ of the German vineyards are planted with FRGVs (Statistisches Bundesamt, 2016). Replanting a vineyard is a business decision with long-lasting consequences. Hence, wine growers plant grape varieties with the best combination of work load and market potential. Pedneault and Provost (2016) trace the wine growers' hesitation regarding FRGVs back to scepticism in terms of the varieties' market potential. The FRGVs with their unfamiliar names and wines with different flavour profiles are new to consumers. Hence, Pedneault and Provost (2016) suggest further research to identify ways to educate consumers with communication strategies. Once wine growers see potential in the sales of FRGVs, they are possibly more open to plant these varieties.

The hesitant adoption of FRGVs among wine growers and consumers is typical for innovations. An idea or a product that appears as new to an individual is described as an innovation (Rogers, 2003). According to Rogers (2003), innovations go through a process of diffusion. His theory states that the spread of an innovation is dependent on the innovation itself, the communication channels among adopters, the adopters' social system, and time. Furthermore, he dissects the adopters into different groups depending on their time of adoption. The venturesome group of the 'innovators' adopt innovations first. They are followed by 'early adopters' who are opinion leaders and communicate a lot about the product or service. The third group is called the 'early majority'. This group adopts the innovation before the average participant whereas the 'late majority' waits until the average participant adopted the innovation. The last group that uses an innovation is called the 'laggards'. The word itself reflects their hesitant attitude. Their focus on tradition and their risk aversion lead to scepticism towards the innovation.

Ram and Sheth (1989) use the theory of innovation resistance to examine the success of the diffusion on innovations. The authors point out that innovations face barriers that cause the resistance for users. These barriers are directly related to the changes that an innovation brings. The barriers can be divided into two groups: the functional barriers and the psychological barriers. The three functional barriers are (1) the usage barrier, (2) the value barrier, and (3) the risk barrier. The usage barrier describes obstacles that users face by following their familiar workflow. The value barrier comes into play when users assess the benefits of an innovation. If the benefits do not outweigh the associated costs, such as workflow changes, users will not adopt the innovation. The risk barrier can be dissected into four types of risk. First, the physical risk represents the fear of physical harm. Second, the economic risk describes that users rather wait for a lower price of the product instead of 
adopting the innovation right after launch. Third, the functional risk stands for the uncertainty regarding the actual performance of an innovation. Last, the social risk stands for the fear that others may make fun of users of the innovation. The two psychological barriers are (1) the tradition barrier and (2) the image barrier. The tradition barrier is an issue when users need to change their habits to adopt an innovation. This barrier is particularly present for food and beverages because eating and drinking habits are hard to change. The image barrier arises from negative associations with an innovation. Users perceive aspects of an innovation as negative and these perceptions are mostly based on stereotypes. Apart from describing these barriers, the authors also introduced strategies to overcome them. For example, risk barriers can be counteracted by using a well-known, trusted brand name or by giving users the possibility to taste the product. The tradition barrier can be tackled with information. Users need education about the innovation and might also rely on change agents that introduce the innovation.

Atkin et al. (2006) use the diffusion theory and the theory of innovation resistance to illustrate the adoption of the screw cap and synthetic cork closures. The multinational study compares the three countries Australia, New Zealand and the United States in terms of the perception of cork, synthetic cork and screw cap closures. The authors define the screw cap closure as a low-tech discontinuous innovation. The discontinuity of this innovation arises from the change of processes for manufacturers and consumers. The screw cap closure needs new bottling facilities and a different bottle design. The consumers' familiar process of opening a bottle of wine with a corkscrew changes to unscrewing a bottle of wine. The ceremony of opening with a tool, tasting, and drinking is reduced to opening by unscrewing and drinking. In this case, the most crucial factor in overcoming the barriers of resistant innovations is educating consumers. According to Atkin et al. (2006), mainstream consumers do not see the benefits of screw caps regarding the avoidance of cork tainted bottles. Therefore, communicating the benefits of this type of closure is a key factor. Another important factor is the elimination of social risk. Consumers should not fear to be ridiculed when bringing a bottle of wine with a screw cap to friends. Hence, the image of the closure needed to be changed. In New Zealand, the wine industry decided to inform consumers and thus improved the image of the screw cap. The study clearly shows that the approach works: New Zealanders have a significantly higher acceptance of the screw cap than the American participants in the study. That study points to a further important factor: the personal attitudes of consumers. Depending on their level of involvement, consumers are more or less likely to adopt screw caps. More involved consumers are more open to the innovative type of closure.

The concept of involvement describes the individual's perceived relevance of a product (Zaichkowsky, 1985). Involvement has been used to analyse consumer behaviour related to various marketing areas, such as risk behaviour (Aqueveque, 2006; Dholakia, 2001; Hong, 2015; Johnson and Bruwer, 2004; Sheth and Venkatesan, 1968), brand evaluation (Harrigan et al., 2018; Kim and Sung, 2009; Lastovicka and Bonfield, 1982; Orth, 2005), segmentation 
(Bruwer et al., 2017; Hirche and Bruwer, 2014; Levitt et al., 2017; Lockshin et al., 2001, 1997; Pomarici et al., 2017; Quester and Smart, 1998) and advertising (Spielmann and Richard, 2013; Zaichkowsky, 1994). Involvement is often used in the context of wine. The complexity of the product leads to consumer groups that differ in their level of involvement. Therefore, the concept proves useful to segment consumer groups. Consumers with high involvement tend to ascribe less importance to the price cue than the less involved consumers (Pomarici et al., 2017; Zaichkowsky, 1988). The level of involvement also influences the definition of wine related terms, such as ‘terroir’ (Spielmann and Gélinas-Chebat, 2012). For the highly involved consumers, the 'terroir' is the synergy of climate, tradition, geography and other factors that, therefore, influence the wine production and the wine. Lowly involved consumers tend to focus on the geographical meaning of 'terroir' and neglect the more technical features. That study is a good example for the consequences of segmentation by involvement. Additionally, extrinsic and intrinsic attributes of the product category wine are valued differently by lowly and highly involved consumers (Bruwer et al., 2017). Further studies confirm that observation for many product cues, such as recommendations, previous experience, grape variety, brand name, and origin (Barber et al., 2007; Hollebeek et al., 2007; Pomarici et al., 2017; Prendergast et al., 2010; Quester and Smart, 1998). In summary, it can be stated that the wine involvement is an established criterion to segment consumers and analyse the consumer behaviour.

The purpose of this dissertation is to examine the consumer acceptance of innovations in the product category wine. In particular, this dissertation analyses the influence of information about the innovation on the consumer acceptance and the importance of environmental friendliness or environmentalism for the adoption of new grape varieties. In addition, the interaction of information and involvement is included in the analysis to understand the consumers' behaviour and to enable the distinction between different levels of involvement. For this reason, the theories of diffusion and innovation resistance are used together with the involvement concept to identify interactions and consumer segments. The innovations that are used to examine ways to speed up the diffusion process are (1) new packaging solutions with varying degrees of innovativeness and (2) fungus resistant grape varieties. The packaging innovations allow the investigation of the influence of information for different degrees of innovativeness. Furthermore, the packaging is an extrinsic cue that is an important part of the perception of a product. The combination with the wine involvement level sheds light on the consumers' attitudes and the behaviour. The FRGVs can be grown in a more environmentally friendly way. Therefore, the interesting question is whether consumers choose wines made from these grapes when they know about these environmental benefits. The innovativeness of the FRGVs causes the consumers' unfamiliarity with these varieties, hence their market share is limited. To gain market share for FRGVs, it is necessary to identify consumer segments that are open to innovations that have an environmental benefit. 
To answer these research questions, three studies have been carried out. The dissertation presents the following three articles. The first article 'Information and involvement: The influence on the acceptance of innovative wine packaging' examines whether information can support overcoming adoption barriers to innovative packaging. The degree of innovation and the level of wine involvement are identified as important factors for the adoption of the packaging. This study is based on an online survey and features three different packaging solutions with varying degrees of innovativeness. The moderated regression analysis reveals that involvement is an important factor for the influence of information. Low involvement consumers react particularly positive on the information, whereas high involved consumers are not affected by the additional information about the advantages of the packaging. The second article 'What about the environment? A choice-based conjoint study about wine' examines the importance of product attributes that are linked to FRGVs. The choice experiment elicits the participants' preferences for FRGV related attributes, such as 'reduction of pesticides', 'reduction of carbon emissions' and 'familiarity with the grape variety'. The conjoint analysis shows that consumers would opt for an unfamiliar grape variety in exchange for benefits for the environment. The cluster analysis based on the choice experiment dissects the participants in three clusters: (1) the green-minded, (2) the traditionalist, and (3) the priceminded. The article states that the attributes related to the environmental benefits of FRGVs are relevant for the participants. The third article 'The role of environmental information for wine innovation adoption - The case of fungus resistant grape varieties' examines the link between information about the environmental benefits of FRGVs and the purchase probability. The study is based on an online survey and uses a within-subject design to evoke the influence of information. The article points out that information about the benefits of FRGVs can accelerate the adoption. The dissertation closes with some conclusions and an outlook for research and practice. 


\section{References}

Adelsheim, D., Busch, C., Catena, L., Champy, B., Coetzee, J., Coia, L., Croser, B., et al. (2016), “Climate Change: Field Reports from Leading Winemakers”, Journal of Wine Economics, Vol. 11 No. 01, pp. 5-47.

Aqueveque, C. (2006), "Extrinsic cues and perceived risk: the influence of consumption situation”, Journal of Consumer Marketing, Vol. 23 No. 5, pp. 237-247.

Ashenfelter, O. and Storchmann, K. (2016), "Climate Change and Wine: A Review of the Economic Implications”, Journal of Wine Economics, Vol. 11 No. 01, pp. 105-138.

Atkin, T., Garcia, R. and Lockshin, L. (2006), “A Multinational Study of the Diffusion of a Discontinuous Innovation”, Australasian Marketing Journal, Elsevier, Vol. 14 No. 2, pp. 17-33.

Atkin, T. and Newton, S. (2012), "Consumer awareness and quality perceptions: a case for Sonoma County wines”, Journal of Wine Research, Vol. 23 No. 2, pp. 155-171.

Barber, N. and Almanza, B. (2006), "Influence of Wine Packaging on Consumers' Decision to Purchase”, Journal of Foodservice Business Research, Vol. 9 No. 4, pp. 83-98.

Barber, N., Ismail, J. and Dodd, T. (2007), "Purchase Attributes of Wine Consumers with Low Involvement”, Journal of Food Products Marketing, Vol. 14 No. 1, pp. 69-86.

Basler, P. and Scherz, R. (2011), PIWI-Rebsorten: pilzwiderstandsfähige Rebsorten, Stutz, Wädenswil.

Bojanowski, A. (2016), "Verzweifelter Kampf gegen Falschen Mehltau”, Spiegel Online, available at: http://www.spiegel.de/wissenschaft/natur/wein-in-deutschland-ernte-starkdezimiert-a-1112956.html (accessed 2 August 2018).

Bruwer, J., Chrysochou, P. and Lesschaeve, I. (2017), "Consumer involvement and knowledge influence on wine choice cue utilisation”, British Food Journal, Vol. 119 No. 4, pp. 830-844.

Celhay, F. and Passebois, J. (2011), "Wine labelling: is it time to break with tradition? A study of the moderating role of perceived risk", International Journal of Wine Business Research, Vol. 23 No. 4, pp. 318-337.

Charters, S. (2006), Wine and Society - The Social and Cultural Context of a Drink, (Charters, S.B.T.-W. and S.,Ed.), Butterworth-Heinemann, Oxford.

Deutsches Weininstitut. (2017), “Deutscher Wein Statistik 2017 / 2018”, Deutsches Weininstitut GmbH, Bodenheim.

Dholakia, U.M. (2001), “A motivational process model of product involvement and consumer risk perception”, European Journal of Marketing, Vol. 35 No. 11/12, pp. 1340-1362.

GfK. (2018), "Verbraucher-Analysen Wein Jahr 2017 basierend auf GfK Consumer Panels”, GfK SE, Nürnberg.

Gómez, M., Martín-Consuegra, D. and Molina, A. (2015), “The importance of packaging in purchase and usage behaviour”, International Journal of Consumer Studies, Vol. 39 No. 3, pp. 203-211.

Harrigan, P., Evers, U., Miles, M.P. and Daly, T. (2018), "Customer engagement and the relationship between involvement, engagement, self-brand connection and brand usage intent”, Journal of Business Research, Elsevier, Vol. 88 No. November, pp. 388-396. 
Hirche, M. and Bruwer, J. (2014), "Buying a Product for an Anticipated Consumption Situation - Observation of High and Low Involved Wine Buyers in a Retail Store”, International Journal of Wine Business Research, Emerald, Vol. 26 No. 4, pp. 295-318.

Hollebeek, L.D., Jaeger, S.R., Brodie, R.J. and Balemi, A. (2007), "The influence of involvement on purchase intention for new world wine”, Food Quality and Preference, Vol. 18 No. 8, pp. 1033-1049.

Hong, I.B. (2015), “Understanding the consumer's online merchant selection process: The roles of product involvement, perceived risk, and trust expectation”, International Journal of Information Management, Elsevier Ltd, Vol. 35 No. 3, pp. 322-336.

International Organisation of Vine and Wine. (2016), “Weltkonjunkturbericht”, Organisation Internationale de la Vigne et du Vin, Paris.

Johnson, T. and Bruwer, J. (2004), "Generic Consumer Risk-Reduction Strategies (RRS) in Wine-Related Lifestyle Segments of the Australian Wine Market", International Journal of Wine Marketing, Vol. 16 No. 1, pp. 5-35.

Kim, J. and Sung, Y. (2009), "Dimensions of purchase-decision involvement: Affective and cognitive involvement in product and brand", Journal of Brand Management, Vol. 16 No. 8, pp. 504-519.

Köppe, J. (2018), “Weinlese beginnt so früh wie nie zuvor”, Spiegel Online, available at: http://www.spiegel.de/wissenschaft/natur/hitze-in-deutschland-weinlese-beginnt-sofrueh-wie-nie-a-1220743.html (accessed 3 August 2018).

Kriener, M. (2014), “Kirschessigfliege bedroht deutschen Wein”, Der Tagesspiegel, available at: https://www.tagesspiegel.de/weltspiegel/jahrgang-2014-kirschessigfliege-bedrohtdeutschen-wein/10771362.html (accessed 13 August 2018).

Lastovicka, J.L. and Bonfield, E.H. (1982), “Do consumers have brand attitudes?”, Journal of Economic Psychology, Vol. 2 No. 1, pp. 57-75.

Levitt, J.A., Zhang, P., DiPietro, R.B. and Meng, F. (2017), "Food tourist segmentation: Attitude, behavioral intentions and travel planning behavior based on food involvement and motivation”, International Journal of Hospitality \& Tourism Administration, Routledge, Vol. 00 No. 00, pp. 1-27.

Lockshin, L., Quester, P. and Spawton, T. (2001), "Segmentation by Involvement or Nationality for Global Retailing: A Cross-national Comparative Study of Wine Shopping Behaviours”, Journal of Wine Research, Vol. 12 No. 3, pp. 223-236.

Lockshin, L.S., Spawton, A.L. and Macintosh, G. (1997), "Using product, brand and purchasing involvement for retail segmentation", Journal of Retailing and Consumer Services, Vol. 4 No. 3, pp. 171-183.

Lopes, P., Sagala, R. and Lockshin, L.S. (2016), "Importance of eco-logo and closure type on consumer expectations, price perception and willingness to purchase wines in Canada”, AAWE Working Papers, Vol. 200 No. July, pp. 1-13.

Mackie, K.A., Müller, T. and Kandeler, E. (2012), "Remediation of copper in vineyards - A mini review”, Environmental Pollution, Elsevier Ltd, Vol. 167, pp. 16-26.

Marin, A.B. and Durham, C.A. (2007), "Effects of Wine Bottle Closure Type on Consumer Purchase Intent and Price Expectation”, American Journal of Enology and Viticulture, Vol. 58 No. 2, pp. 192-201.

McDaniel, C. and Baker, R.C. (1977), "Convenience Food Packaging and the Perception of Product Quality”, Journal of Marketing, Vol. 41 No. 4, pp. 57-58. 
Nancarrow, C., Wright, L.T. and Brace, I. (1998), "Gaining competitive advantage from packaging and labelling in marketing communications”, British Food Journal, MCB UP Ltd, Vol. 100 No. 2, pp. 110-118.

Orth, U. (2005), "Consumer personality and other factors in situational brand choice variation”, Journal of Brand Management, Vol. 13 No. 2, pp. 115-133.

Pedneault, K. and Provost, C. (2016), "Fungus resistant grape varieties as a suitable alternative for organic wine production: Benefits, limits, and challenges”, Scientia Horticulturae, Elsevier B.V., doi:10.1016/j.scienta.2016.03.016.

Pomarici, E., Lerro, M., Chrysochou, P., Vecchio, R. and Krystallis, A. (2017), "One size does (obviously not) fit all: Using product attributes for wine market segmentation”, Wine Economics and Policy, Elsevier B.V., Vol. 6 No. 2, pp. 98-106.

Prendergast, G.P., Tsang, A.S.L. and Chan, C.N.W. (2010), "The interactive influence of country of origin of brand and product involvement on purchase intention", Journal of Consumer Marketing, Vol. 27 No. 2, pp. 180-188.

Quester, P.G. and Smart, J. (1998), "The influence of consumption situation and product involvement over consumers' use of product attribute”, Journal of Consumer Marketing, Vol. 15 No. 3, pp. 220-238.

Ram, S. and Sheth, J.N. (1989), "Consumer Resistance to Innovations: The Marketing Problem and its solutions”, Journal of Consumer Marketing, MCB UP Ltd, Vol. 6 No. 2, pp. 5-14.

Rigaux-Bricmont, B. (1982), “Influences of brand name and packaging on perceived quality”, Advances in Consumer Research, Vol. 9 No. 1, pp. 472-477.

Rogers, E.M. (2003), Diffusion of Innovations, The Free Press, New York, 5thed.

Rundh, B. (2009), "Packaging design: Creating competitive advantage with product packaging”, British Food Journal, Vol. 111 No. 9, pp. 988-1002.

Rundh, B. (2016), “The role of packaging within marketing and value creation”, British Food Journal, Vol. 118 No. 10, pp. 2491-2511.

Sara, R. (1990), "Packaging as a Retail Marketing Tool”, International Journal of Physical Distribution \& Logistics Management, Vol. 20 No. 8, pp. 29-30.

Schoormans, J.P.L. and Robben, H.S.J. (1997), "The effect of new package design on product attention, categorization and evaluation”, Journal of Economic Psychology, Vol. 18 No. 2-3, pp. 271-287.

Schultz, H.R. (2016), "Global Climate Change, Sustainability, and Some Challenges for Grape and Wine Production”, Journal of Wine Economics, Vol. 11 No. 01, pp. 181-200.

Sherman, S. and Tuten, T. (2011), "Message on a bottle: the wine label's influence", International Journal of Wine Business Research, Vol. 23 No. 3, pp. 221-234.

Sheth, J.N. and Venkatesan, M. (1968), "Risk-Reduction Processes in Repetitive Consumer Behavior”, Journal of Marketing Research, Vol. 5 No. 3, p. 307.

Silayoi, P. and Speece, M. (2007), "The importance of packaging attributes: a conjoint analysis approach”, European Journal of Marketing, Vol. 41 No. 11/12, pp. 1495-1517.

Spielmann, N. and Gélinas-Chebat, C. (2012), “Terroir? That's not how I would describe it", International Journal of Wine Business Research, Vol. 24 No. 4, pp. 254-270. 
Spielmann, N. and Richard, M.O. (2013), "How captive is your audience? Defining overall advertising involvement”, Journal of Business Research, Elsevier Inc., Vol. 66 No. 4, pp. 499-505.

Statistisches Bundesamt. (2016), “Grunderhebung der Rebflächen”, Fachserie 3, R 3.1.5, 2015, Statistisches Bundesamt, Wiesbaden.

Töpfer, R., Maul, E. and Eibach, R. (2011), “Geschichte und Entwicklung der Rebenzüchtung auf dem Geilweilerhof”, Schriften zur Weingeschichte, No. 172, pp. 1-24.

Veale, R. (2008), “Sensing or knowing?: Investigating the influence of knowledge and selfconfidence on consumer beliefs regarding the effect of extrinsic cues on wine quality", International Journal of Wine Business Research, Vol. 20 No. 4, pp. 352-366.

Viot, C. (2012), "Subjective knowledge, product attributes and consideration set: a wine application”, International Journal of Wine Business Research, Vol. 24 No. 3, pp. 219248.

Zaichkowsky, J.L. (1985), "Measuring the Involvement Construct”, Journal of Consumer Research, Vol. 12 No. 3, p. 341.

Zaichkowsky, J.L. (1988), "Involvement and the Price Cue", Advances in Consumer Research, Vol. 15 No. 1, pp. 323-327.

Zaichkowsky, J.L. (1994), “The Personal Involvement Inventory: Reduction, Revision, and Application to Advertising”, Journal of Advertising, Vol. 23 No. 4, pp. 59-70. 


\section{Information and involvement: The influence on the acceptance of innovative wine packaging}

Lucas Nesselhauf, Johannes Deker and Ruth Fleuchaus

This article is published in a similar version in the

International Journal of Wine Business Research

2017, Vol. 29 Issue: 3, pp. 285 - 298

doi.org/10.1108/IJWBR-08-2016-0026 


\begin{abstract}
Purpose: This paper suggests that consumer education in the form of information can effectively overcome adoption barriers to new and innovative wine packaging. This effectiveness depends on both, the degree in packaging innovation and the level of consumer involvement.
\end{abstract}

Design/methodology/approach: The paper is based on an online experiment with a sample of 427 German consumers to analyse the perception of consumers for innovative packaging. The experiment featured three different packaging options: bottles with screw cap closures, bag-inbox, and StackWine. For each packaging form, a treatment group with additional information about the packaging and a reference group without this information was surveyed. ANOVAs and t-tests were carried out to test the hypotheses. A moderated regression analysis was used to examine the effect of involvement in combination with information on intention to buy.

Findings: The results revealed that low involvement consumers react positively to additional information about the benefits of a new packaging. For highly involved consumers, however, the effect of information is not significant. Furthermore, the analysis showed that consumers with low involvement mainly buy wine in supermarkets.

Practical implications: Information about new packaging forms should be presented in places where consumers with low involvement buy wine, such as supermarkets. These consumers can be influenced by the additional information about the innovative packaging.

Originality/value: The use of a moderated regression analysis in the context of wine packaging and involvement is a first and reveals new and valuable insights.

Keywords: packaging, innovation, consumer behaviour, involvement, consumer education 


\section{Introduction}

Are bottles outdated? Nowadays, wine comes in many different shapes and sizes: Bottles with corks, screw caps or stoppers, larger containers like bag-in-box and Tetra Pak ${ }^{\circledR}$, and the single serving packaging like StackWine or cans. Producers want to stand out of the masses in the market and, therefore, the labelling and also the packaging are very important. In particular, the German wine market is very competitive. The competitive environment is based on two facts: first, Germany is an import market and second, discounters with their low prices play a key role in the market. In 2015, the Germans consumed 20.6 million hl wine and $55 \%$ of this consumed wine was imported (DWI, 2016). In total, Germany imported 15.1 million hl wine in 2015 (International Organisation of Vine and Wine, 2016). In the same year, France only imported 7.8 million hl wine (International Organisation of Vine and Wine, 2016), but the French consumed more than 27 million hl wine (DWI, 2016). In general, Germany imports more wine than any other country in the world (International Organisation of Vine and Wine, 2016).

Referring to the major role of discounters, the Germans bought 14.3 million hl wine to consume at home, thereof they bought 7 million hl in discounters and 3.7 million hl in supermarkets (DWI, 2016). 1.9 million hl were bought at the cellar door and only 1.7 million hl were bought in dedicated wine shops (DWI, 2016). Thus, German consumers mostly buy wine in shops without expert service and, therefore, the packaging plays a key role.

Hence, the wine market is changing in terms of packaging. Producers break with traditions and introduce new packaging forms (Barber and Almanza, 2006). Bag-in-box sales have steadily increased over the last few years (Santini et al., 2007) and the International Organisation of Vine and Wine (2013) has proposed to the World Customs Organisation to change the custom identification of containers between 2 and 10 litres, which demonstrates the importance of this type of packaging.

However, innovative packaging face the same barriers as any other innovation (Atkin et al., 2006). Despite this fact, the adoption of innovative packaging attracted little attention in previous research. Especially radically innovative packaging forms like StackWine have not been addressed in the realm of consumer acceptance of innovations. Therefore, the aim of this paper is to shed light on the acceptance of radical packaging innovations in the wine market. This study particularly examines the effect of consumer education as well as the influence of product involvement on the acceptance of new packaging forms. In doing so, this study makes several contributions to research regarding the adoption of innovative packaging. First, this study shows how consumers react to different types of packaging with respect to the degree of discontinuity. Second, this study demonstrates how information about the benefits of a new packaging and level of product involvement are related. Finally, the study's results inform managers how new types of packaging can be introduced to the consumers. 


\section{Literature review}

\subsection{Packaging}

Packaging is one of the last chances to persuade a consumer to choose one item over another (McDaniel and Baker, 1977). Therefore, it can significantly influence consumers’ purchase decisions. Rigaux-Bricmont (1982) shows that packaging is a powerful way to differentiate products from competitors. Especially food packaging greatly influences the purchase decisions. In addition to the important role of protecting and keeping perishable goods fresh and consumable, packaging helps consumers find the right product (Wells et al., 2007). Consumers, however, do not only value the form and function of a packaging. In fact, consumers appreciate altruistic and social features of a packaging design as well (Kumar and Noble, 2015). Orth and Malkewitz (2008) define five holistic packaging design prototypes, each of which consists of a specific set of design elements and factors that trigger certain design impressions in consumers' minds.

Since wine is a very complex product whose quality cannot be adequately assessed prior to its purchase or consumption, consumers rely on extrinsic cues such as the packaging and the information displayed on the packaging (Atkin and Newton, 2012; Sherman and Tuten, 2011). There is empirical evidence showing that extrinsic cues like label design, type of closure, region of origin, and price influence the purchase decision and even the post-purchase evaluation of quality significantly (Atkin et al., 2006; Atkin and Newton, 2012; Barber and Almanza, 2006; Celhay and Passebois, 2011; Sherman and Tuten, 2011; Veale, 2008). One part of the packaging is particularly interesting for the wine marketing research: the closure (e.g. Murray and Lockshin, 1997). Barber et al. (2008) also take a look at the closure and how American consumers accept new types of closure like screw caps and synthetic corks. The authors underline the importance of the packaging and the closure for specific situations like gift giving and dinner parties.

\subsection{Innovation and adoption}

The consumers' adoption process is a subject of high interest in both academia and practice (Hauser et al., 2006; Ma et al., 2014; Rogers, 1976, 2003). Rogers (2003) has formulated the common adoption process for new products. That process is divided into five steps: knowledge, persuasion, decision, implementation, and confirmation (Rogers, 2003). Those five steps cover the whole process from the first knowledge about the product over the purchase decision up to the decision about further use of this product. Numerous further studies have examined different factors influencing the adoption process. For example, the adoption of new products is affected by the perceived number of adopters within a target group in combination with the consumers' wish for assimilation or distinctiveness (Timmor and Katz-Navon, 2008). Moreover, extrinsic cues that reduce the risks associated with the new product (e.g. warranties) can foster new product adoption as well (Bearden and Shimp, 1982). In addition to influences of extrinsic cues 
and group dynamics, consumers want to be informed about new products and their benefits. Thus, marketing activities need to support the launch of new products. However, the timing of marketing activities is crucial for their efficacy (Delre et al., 2007). Especially during the launch phase, traditional advertising activities can highly impact the adoption (Narayanan et al., 2005). Information about the benefits of a new product feature supports the adoption. For example, research shows that consumer education, such as information about an innovation, can alter the preference of different types of closure. In fact, consumers showed higher preferences for synthetic cork closures after reading an informative article about this new type of closure (Murray and Lockshin, 1997).

Ram and Sheth (1989) discuss the concept of resistance to innovations. One characteristic of innovation resistance is that innovation resistance occurs in every product category and solely depends on the degree of discontinuity (Ram and Sheth, 1989). Furthermore, they differentiate between functional and psychological barriers that innovative products have to overcome. Functional barriers include usage, value and risk barriers; psychological barriers can be divided into tradition and image barriers (Ram and Sheth, 1989). Since the adoption depends on the degree of discontinuity, products with a high level of discontinuity face stronger adoption barriers than those with lower levels of discontinuity. However, even these low innovative products can face strong resistance, particularly if a conflict with the consumers' tradition and image structure occurs (Ram and Sheth, 1989). Laukkanen et al. (2007) show the strong influence of psychological barriers for mature consumers and the adoption of mobile banking. Although, young and mature consumers perceived the innovation similarly in terms of usage and value, the mature consumers put more weight on the risk barrier and the psychological barriers (Laukkanen et al., 2007).

Atkin et al. (2006) use that concept of resistance to innovation to analyse the adoption of screw cap closures for wine bottles in New Zealand, the United States, and Australia. The authors define the screw cap closure as a low-tech discontinuous innovation because the action of opening the bottle is different: no tool is needed and the bottle can be closed again easily (Atkin et al., 2006). That study's main finding is that information about the new features of a discontinuous innovation helps diffusion.

\subsection{Involvement}

Zaichkowsky (1988) introduces product involvement as the individual's perceived relevance of a product or product category. High involvement consumers evaluate extrinsic product cues differently than low involvement consumers. Involvement also leads to different consideration of extrinsic cues like the country of origin of the brand; low involvement consumers tend to pay more attention to this cue than highly involved consumers (Prendergast et al., 2010). There is a multitude of research about wine and involvement showing that the level of involvement has a significant influence on the consideration and understanding of different extrinsic and intrinsic cues (Bruwer and Buller, 2013; Fernandes Ferreira Madureira and Simões de Sousa Nunes, 
2013; Hollebeek and Brodie, 2009; Spielmann, 2012). Concerning wine consumers, Hirche and Bruwer (2014) show that involvement influences consumer behaviour significantly. For example, the situations the wine is bought for and the consumption patterns change with different involvement levels (Hirche and Bruwer, 2014; Quester and Smart, 1998). Furthermore, Hirche and Bruwer (2014) show that product quality cues like grape variety, region, and brand are more important for consumers that are highly involved in wine than for those with a lower level of involvement. Moreover, the consumers' price sensitivity is also dependent on their level of involvement; consumers with higher levels of involvement pay less attention to the price (Barber et al., 2008; Hollebeek et al., 2007; Quester and Smart, 1998). Rahman and Reynolds (2015) point out that the involvement induced differences in perception are not just hypothetical but are also observable in tastings and present in the consumers quality evaluation. Hence, the mentioned differences in behaviour suggest that consumer segmentation based on involvement would be beneficial for vineyards. In fact, Lockshin and Spawton (2001) state that consumers can be divided into groups based on their involvement level. Therefore, vineyards should consider the consumers' involvement levels in order to address the different needs and expectations with the right marketing strategy (Lockshin and Spawton, 2001).

In conclusion, the degree of discontinuity of an innovation, the available information about an innovation, and the consumers' involvement in the product category influence the acceptance of an innovation. Thus, the relationships among these constructs is of crucial importance for the development of new packaging and the presumed adoption of such innovations.

\section{Hypotheses development}

Building on the insights from the literature review, the definition of the degree of discontinuity follows Atkin et al. (2006). In this sense, a more radical innovation deviates more from the reference product. In this case, information is an unbiased list of facts about the benefits of the packaging innovation, which is specific to each packaging innovation. This definition follows the suggestion of Atkin et al. (2006) that information fosters adoption of innovations. According to Zaichkowsky (1988), involvement expresses the consumer's perceived relevance of wine. In this study, acceptance represents the consumers' willingness to buy wine in this specific packaging form. Figure 1 visualises the presumed relationships between the four constructs.

Figure 1: Visualisation of the hypotheses

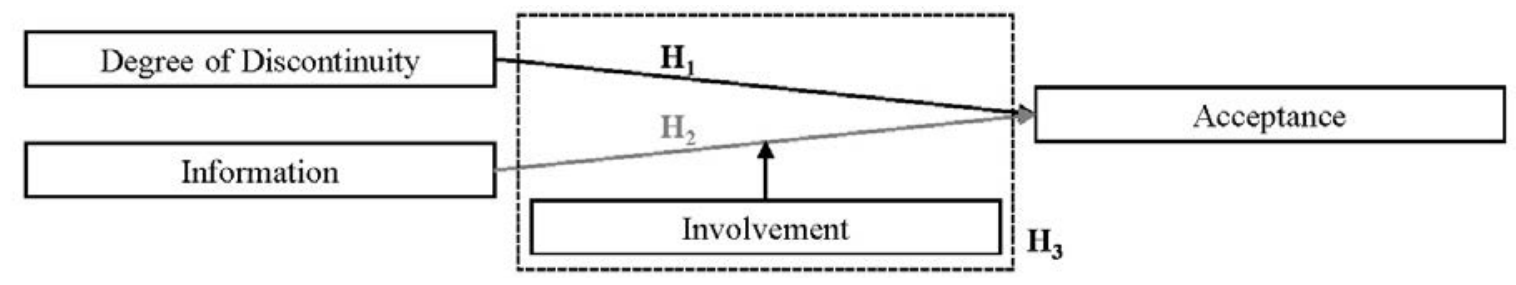


Based on the aforementioned definitions and the insights derived from section 2.2 of the literature review, more radical packaging face stronger consumer acceptance barriers. Accordingly, this leads to the following hypothesis:

$\mathrm{H}_{1}$ : The consumer acceptance of the packaging innovation is inversely related to the degree of discontinuity of package design.

Moreover, consumer education in form of information, according to Atkin et al. (2006) about the beneficial features of an innovative packaging, is expected to have a positive effect on every packaging option. Thus, these reflections lead to the following hypothesis:

$\mathrm{H}_{2}$ : Information about the innovative packaging's beneficial features enhances consumer acceptance of the packaging.

Lastly, consumer involvement also has an impact on the acceptance of the packaging innovation. Since consumer involvement reflects the consumers' subjective relevance of wine and correlates with the expertise about wine (Famularo et al., 2010), the influence of information about the packaging might differ for different levels of consumer involvement. Due to the lower level of knowledge, low involvement consumers might be more open to information about new packaging forms. As already mentioned in section 2.1 and 2.3, consumers with different levels of involvement behave and value product attributes differently. Since low involvement consumers place more importance on extrinsic attributes like price and labels (Barber et al., 2008; Hollebeek et al., 2007), information about the packaging might be more useful for them. As a consequence, information has a positive effect. Furthermore, lowly involved consumers might be more interested in the information since they might treat wine with less emotion and less affection. Therefore, these considerations lead to the following final hypothesis:

$\mathrm{H}_{3}$ : The positive effect of information about the packaging on the consumer acceptance is greater for consumers with low involvement than for those with high involvement.

The three hypotheses focus on the acceptance of the different packaging forms in combination with information and involvement. In addition to these three hypotheses, the study covers the usual place of purchase to incorporate the special situation of the German wine market (see section 1). Furthermore, to gain more insights in the consumer behaviour, the place of purchase will be combined with different levels of involvement. How the design of the study reflects each part of the hypotheses is part of the next section.

\section{Method}

The setup for this study was a 3 (degree of discontinuity) x 2 (information presentation) factorial between-subjects design in an online experiment with 427 German consumers. The degree of discontinuity is reflected by the three different wine packing options that differ in the way 
consumers drink the wine (see Table 1). Hence, they refer to different degrees of discontinuity and imply different consequences for the adoption process. Since the bottle with cork closure is the best-known wine packaging in Germany, this type of packaging is used as a reference for the following considerations. Therefore, the bottle with a screw cap closure (SC) represents the least radical innovation. The process of consuming wine is mainly identical, the only difference is the opening of the bottle referring to the definition of Atkin et al. (2006). In line with this definition, for bag-in-box wines $(\mathrm{BiB})$, the consumption process is rather different: There is no glass bottle and the container is significantly larger. The wine is still consumed out of a usual glass. Thus, it can be argued that the degree of discontinuity is on a medium level. The differences between a bag-in-box and a bottle with a cork closure are considerably greater than the difference between a bottle with cork closure and a bottle with screw cap closure. StackWine (SW) represents the highest degree of discontinuity because the form of the container is completely different and there is no need for additional glasses for consuming the wine. The plastic containers are developed for casual activities and outdoor events. One of the most significant differences is that this type of packaging just serves a single person. The different levels of discontinuity have been assigned to each of the three packaging options by carrying on the definitions by Atkin et al. (2006) and applying those to these packaging.

Table 1: Packaging options in this study

\begin{tabular}{|c|c|c|c|}
\hline Packaging & $\begin{array}{c}\text { Bottle with Screw Cap } \\
\text { (SC) }\end{array}$ & $\begin{array}{l}\text { Bag-in-box } \\
\quad \text { (BiB) }\end{array}$ & $\begin{array}{l}\text { StackWine } \\
\quad(\mathrm{SW})\end{array}$ \\
\hline \multicolumn{4}{|l|}{ Visualisation } \\
\hline Description & $\begin{array}{l}0.75 \text { litre bottle with } \\
\text { screw cap closure }\end{array}$ & 3 litre bag-in-box & $\begin{array}{c}\text { Four single serving } \\
\text { plastic glasses } \\
\text { (total } 0.75 \text { litre) }\end{array}$ \\
\hline $\begin{array}{l}\text { Degree of } \\
\text { Discontinuity }\end{array}$ & Low & Medium & High \\
\hline
\end{tabular}

The presentation of the packaging form was integrated into the online experiment in the form of a series of pictures or a video (StackWine). The process of opening the packaging and pouring the wine into a glass was depicted for the two packaging forms bottle with screw cap closure and bag-in-box. The concept of StackWine was presented in a short advertising video of the company. The participants, therefore, knew how the packaging works even if they had never seen the packaging in real life before. The information texts about the benefits of the packaging forms included features like the possibility to open the bottle or container without a 
tool to close the bottle again or to prevent oxidation. In addition to these convenience related benefits, for the packaging bag-in-box, the text also stated the benefits for the environment.

Table 2: Wine product involvement construct by Hirche \& Bruwer (2014)

- I have good general knowledge about wine. - Every now and then I visit a wine seminar.

- Other people often ask me advice regarding - Sometimes, when drinking wine, I like the wine. intellectual challenge of complex tastes.

- Wine offers me relaxation and fun when - I am or would consider getting a member in life’s pressures build up. a wine club.

- I take particular pleasure from wine. - I regularly attend wine events / festivals.

- I very much enjoy spending time in a wine shop.

- Every now and then I participate at a wine tasting.

The participants' intention to buy was used as a measurement of acceptance of the packaging ("I would buy wine in this packaging”, 7-point Likert scale). Involvement was measured using the ten items wine product involvement construct (7-point Likert scale) developed by Hirche and Bruwer (2014), see Table 2. Additionally, the personal involvement inventory by Zaichkowsky (1994) was polled. Due to a lower Cronbach's $\alpha(0.897)$ of that involvement construct, however, the wine product involvement scale was used for all further analyses. Furthermore, participants' demographic data and the place of purchase (supermarket, wine shop, online wine shop, vineyard cellar door, vineyard online) were obtained.

\section{Data analysis and results}

First, a pilot study with 15 participants was conducted to test the setup technically, the wording of the items in translation, and the unambiguity of the items. In the main online experiment, a total of 427 participants were randomly assigned to the six conditions of a 3 (packaging: SC, $\mathrm{BiB}, \mathrm{SW}$ ) x 2 (information about benefits: yes vs. no) factorial between-subjects design. The resulting cell sizes ranged from 63 to 75 . The participants were incentivized with a prize to take part in the online experiment; most of the participants were approached in wine related Facebook groups. The participants' mean age is 30 years, $49.9 \%$ of the participants are male and $48.7 \%$ are female. Overall, $51.5 \%$ of the respondents stated to be students. The distribution of these demographic characteristics among the six groups is homogeneous as an ANOVA for age, and chi-squared tests for gender and job showed no significant differences (age: $d f=5 ; F$ $=1.450 ; p=0.205$; gender: $d f=5 ; \chi^{2}=4.717 ; p=0.451$; job: $d f=5 ; \chi^{2}=1.794 ; p=0.877$ ).

An exploratory factor analysis of the construct 'wine product involvement' extracted one factor showing the unidimensionality of the construct. The Cronbach's $\alpha$ of the construct is 0.931 underlining a high reliability of the construct. The median of the wine product involvement is 3.70; the mean is 3.84. Hirche and Bruwer (2014) use the median to segment the participants 
into the groups of low and high involvement. The segmentation was not necessary for this study since the moderated regression analysis is capable of dealing with continuous moderators.

To analyse $\mathrm{H}_{1}$, a one-way ANOVA in combination with planned contrasts was carried out. The ANOVA shows a significant effect of the packaging on the intention to buy, $F(2.424)=173.24$; $p<0.05 ; \omega=0.67$. The three planned contrasts (see Table 3) show that the participants' acceptance of screw caps is significantly higher than for bag-in-box and StackWine. The difference of the acceptance between bag-in-box and StackWine is not significant.

Table 3: Planned contrasts of the packaging options

\begin{tabular}{lcccccc}
\hline Contrast & Mean Difference & Std. Error & $\mathrm{t}$ & $\mathrm{df}$ & Sig. (2-tailed) & $\mathrm{r}$ \\
\hline $\mathrm{SC}>\mathrm{BiB}$ & 3.22 & 0.202 & 15.92 & 261.336 & 0.000 & 0.70 \\
$\mathrm{SC}>\mathrm{SW}$ & 3.51 & 0.198 & 17.79 & 248.805 & 0.000 & 0.75 \\
$\mathrm{BiB}>\mathrm{SW}$ & 0.29 & 0.230 & 1.28 & 279.984 & 0.201 & 0.08 \\
\hline
\end{tabular}

Overall, the results of the contrast tests show that only the tests ' $\mathrm{SC}>\mathrm{BiB}$ ' and ' $\mathrm{SC}>\mathrm{SW}$ ' are significant. Because the third test's result $(\mathrm{BiB}>\mathrm{SW})$ is not significant, $\mathrm{H}_{1}$ is only partly supported. There are statistically significant differences among the three packaging regarding the respondents' intention to buy. The assumed order with a decreasing acceptance from screw cap to StackWine, however, cannot be identified. The acceptances for bag-in-box and StackWine are on the same level, the acceptance for screw cap closures is significantly higher $(p<0.000)$. The values of $r$ for the two planned contrast tests between screw caps and bag-inbox and between screw cap and StackWine of 0.7 respectively 0.75 show strong effect sizes according to Cohen (1992). This effect size underlines the significance of the difference in the consumers' acceptance.

Table 4: t-tests of the effect of information on acceptance

\begin{tabular}{|c|c|c|c|c|c|c|}
\hline \multirow{2}{*}{ Test } & \multicolumn{2}{|c|}{ Levene’s Test } & \multicolumn{4}{|c|}{ t-test } \\
\hline & $\mathrm{F}$ & Sig. & $\mathrm{t}$ & $\mathrm{df}$ & Sig. (2-tailed) & $r$ \\
\hline $\mathrm{SC}_{1}>\mathrm{SC}_{0}$ & 0.031 & 0.859 & 0.328 & 143 & 0.372 & 0.03 \\
\hline $\mathrm{BiB}_{1}>\mathrm{BiB}_{0}$ & 2.088 & 0.151 & 0.731 & 145 & 0.233 & 0.06 \\
\hline $\mathrm{SW}_{1}>\mathrm{SW}_{0}$ & 0.002 & 0.967 & 0.173 & 133 & 0.432 & 0.01 \\
\hline
\end{tabular}

Next, to examine the positive effects of information about the packaging on the consumer acceptance of the packaging proposed in $\mathrm{H}_{2}$, three individual independent sample t-tests were carried out. Each t-test compares the means of the two different groups within one packaging: with information ( $\left.\mathrm{SC}_{1}, \mathrm{BiB}_{1}, \mathrm{SW}_{1}\right)$ and without information $\left(\mathrm{SC}_{0}, \mathrm{BiB}_{0}, \mathrm{SW}_{0}\right)$. Table 4 shows the results of the three t-tests and the corresponding Levene's tests. These results state that there is no significant difference $(\alpha=0.05)$ between the groups with information about the features of the packaging and the groups without that information. Therefore, there is no mere effect of information on intention to buy. Hence, $\mathrm{H}_{2}$ is not supported by the data. 
Table 5: Results of the moderated regression analysis on intention to buy

\begin{tabular}{lccccc}
\hline Predictor & & $\mathrm{B}$ & Std. Error & $\mathrm{t}$ & Sig. \\
\hline Constant & $\mathrm{b}_{0}$ & 2.816 & 0.310 & 9.808 & 0.000 \\
Information (X) & $\mathrm{b}_{1}$ & 0.978 & 0.445 & 2.196 & 0.029 \\
Involvement (M) & $\mathrm{b}_{2}$ & -0.021 & 0.074 & -0.289 & 0.773 \\
Interaction (XM) & $\mathrm{b}_{3}$ & -0.217 & 0.107 & -2.031 & 0.043 \\
Packaging (C) & $\mathrm{b}_{4}$ & 3.334 & 0.180 & 18.521 & 0.000 \\
\hline
\end{tabular}

r of the model: 0.678

r change due to interaction: 0.073 Significance of r change: 0.043

Equation: $Y=2.816+0.978 \times X-0.021 \times M-0.217 \times X M+3.334 \times C$

To analyse the moderating effect of involvement in $\mathrm{H}_{3}$, a moderated regression analysis was performed using the data of all 427 respondents. The binary variable $\mathrm{X}$ represents whether there was information about the features (1) or not (0). Because the respondents do not differentiate between the intentions to buy wine in the packaging bag-in-box or StackWine, these two types of packaging were summarized in one cluster ('more radical packaging'). The screw cap closure stands for the 'less radical packaging'. The bivariate covariate $\mathrm{C}$ represents these clusters $(0=$ 'more radical'; 1 = 'less radical'). The moderator M shows the involvement (range: 1 to 7). The intention to buy is the dependent variable $\mathrm{Y}$ (range: 1 to 7 ).

Figure 2: Visual representation of the moderated regression analysis

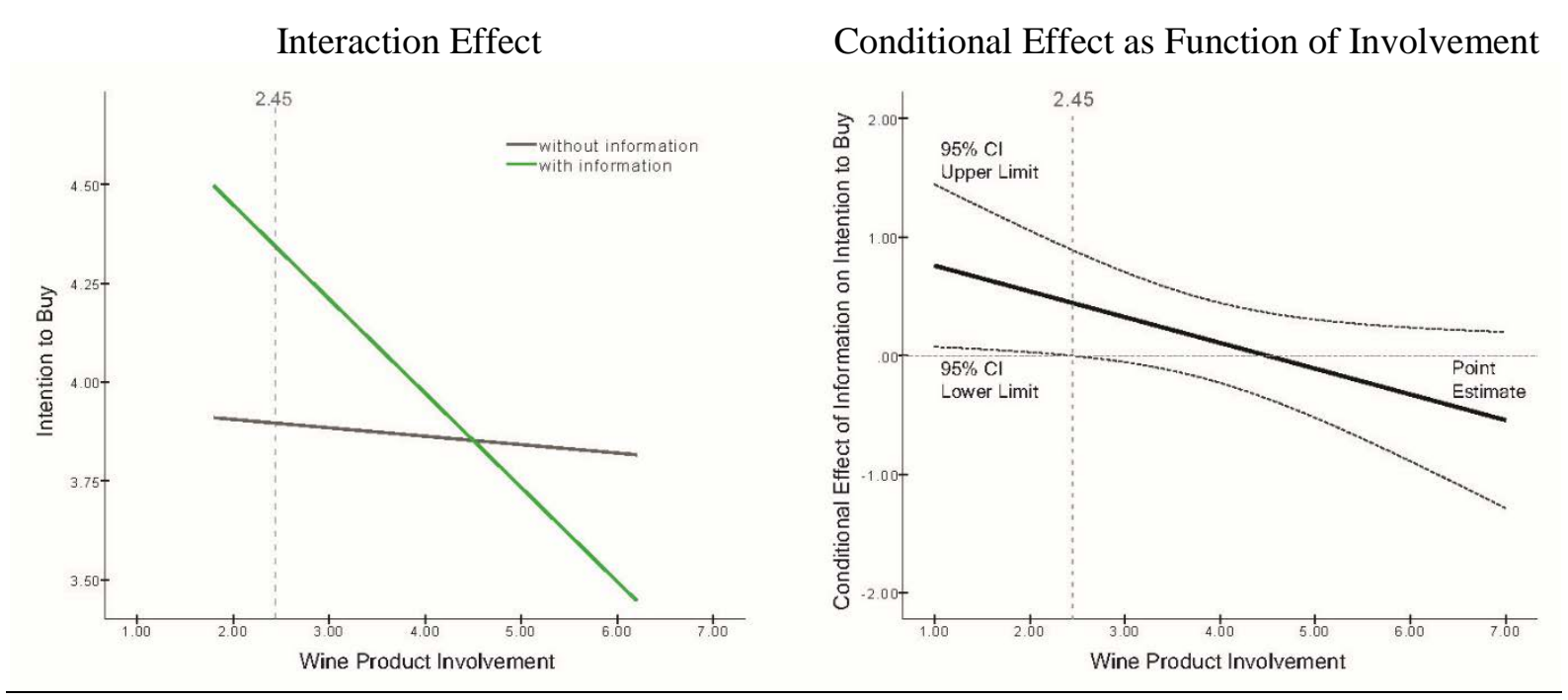

Notes: The covariate C is set to its sample mean 0.340 .

IBM SPSS 22 and Hayes’ plug-in PROCESS (Hayes, 2013) was used to carry out the moderated regression analysis in combination with a floodlight analysis. The floodlight analysis is a tool to identify the moderator's range of significance in moderated regression analyses (Spiller et al., 2013). This technique allows a precise analysis of the moderator. Instead of splitting the data into two groups (e.g. low and high involvement), it is possible to state an exact range of significance for the moderator. Thus, it is not necessary to split the continuous variable 
involvement into groups. The floodlight analysis reveals that information has an effect on the intention to buy for consumers with low levels of involvement. Table 5 shows the results of the moderated regression analysis. The $r$ of the model is 0.678 and 0.073 can be assigned to the inclusion of the interaction effect. The results of the floodlight analysis in Figure 2 show that the effect of information on the intention to buy is significant $(\alpha=0.05)$ for respondents with involvement levels lower than 2.45. Within the sample, $22.5 \%$ of the respondents have an involvement score lower than 2.45. Since the interaction effect of information and involvement is only significant for low levels of involvement, hypothesis $\mathrm{H}_{3}$ is supported.

Since the consumers' preferred place of purchase is important for targeted marketing activities, the place of purchase was another part of the survey. The participants could choose among the five places 'supermarket', 'wine shop', 'vineyard (cellar door), 'online wine shop', and 'vineyard (online)'. Multiple responses were allowed for this question. The answers significantly show that most of the participants (70\%) buy wine in supermarkets. $54 \%$ of the participants shop in wine shops and $50 \%$ of the participants buy wine directly on the premises of vineyards. Only $20 \%$ use the possibility to order wine online from wine shops, and even fewer respondents answered that they buy wine online directly from vineyards. Looking at the place of purchase in combination with the level of involvement, it becomes apparent that consumers with a low level of involvement tend to buy wine mostly in supermarkets. The more involved consumers prefer dedicated outlets for wine - offline and online. These consumers seem to avoid buying wine in supermarkets. Figure 3 shows the results of this analysis.

Figure 3: Place of purchase by level of wine product involvement

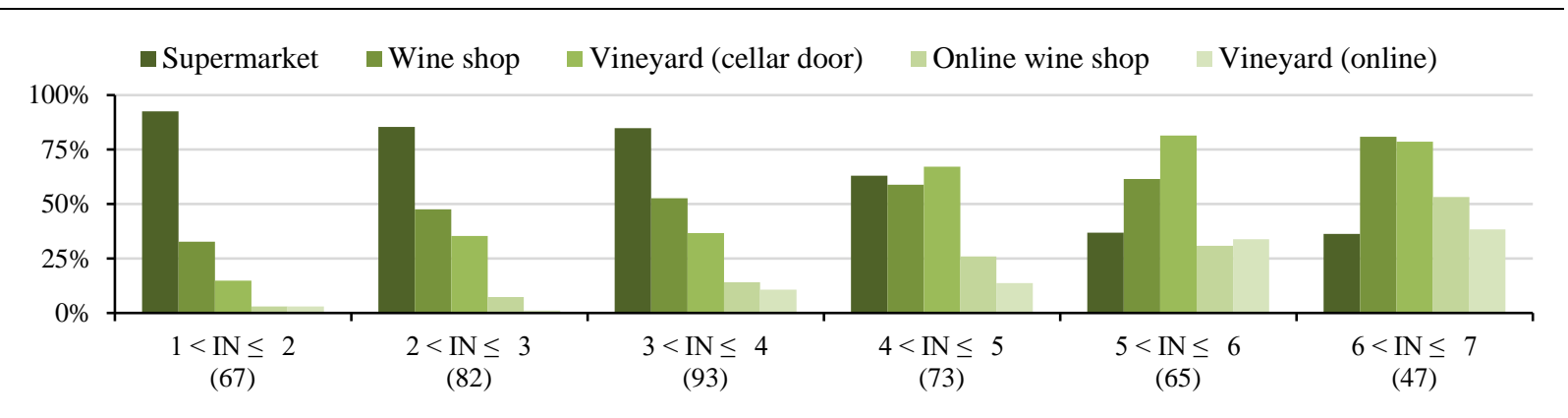

Percentage of positive answers per level of wine product involvement. Multiple answers possible. Numbers '(67)' represent the number of respondents in this class of involvement.

\section{Conclusion and future directions}

\subsection{Conclusions}

There is limited research on the acceptance of innovative packaging. This study focuses on innovative wine packaging and the influence of consumer education and involvement. At first, the differences in the acceptance of the packaging options indicate that the respondents differentiate between two levels of discontinuity. The respondents show the same level of acceptance for StackWine and bag-in-box, but a significantly higher acceptance for the bottle 
with screw cap closure. Therefore, the general assumption that a lower degree of discontinuity correlates with a higher acceptance of the packaging can be supported. Testing hypothesis $\mathrm{H}_{2}$ revealed that the information about the beneficial features of a packaging does not enhance the acceptance among consumers in general. The results of testing hypothesis $\mathrm{H}_{3}$ show why information does not influence the acceptance in general: The acceptance is moderated by the level of wine product involvement. The data shows that low involvement consumers react positively to information about the beneficial features of the packaging. For consumers with higher levels of involvement, the information has no significant influence on the acceptance.

This result highlights the importance of involvement in understanding consumer behaviour with regard to wine. Furthermore, involvement can serve as a basis for powerful consumer segmentation. Many studies before this one have shown that involvement is a useful segmentation factor (e.g. Hirche and Bruwer, 2014; Lockshin and Corsi, 2012). Furthermore, involvement does not only influence the efficacy of information but also the consumers' preferred place of purchase.

The analysis of the place of purchase shows that low involvement wine consumers prefer to buy wine in supermarkets. Since information about the packaging affects this group of consumers the most, the information should be accessible in supermarkets. These consumers with lower levels of involvement can be convinced of the benefits a new packaging can offer. Highly and medium involved consumers prefer the direct contact, consulting and the product range a dedicated wine shop or a shop on the premises of a vineyard can provide. These consumers might be open to new packaging if the sales personnel can describe the benefits directly.

\subsection{Practical implications}

This study's results are very relevant for vineyards and retailers promoting new packaging. Information about the benefits of a new packaging can enhance the acceptance among consumers and therefore this information should be visible either on the shelf or directly on the packaging. For example, instructions how to use bag-in-boxes are common on the packaging, however, the benefits regarding the environment and the convenience are not mentioned. The information is particularly relevant for packaging that are not (yet) common in the respective markets. Furthermore, marketing activities regarding the new packaging form combined with a higher availability of the specific packaging would boost the acceptance. In particular, a wellknown brand representing high-quality wines could be very successful by introducing entrylevel wines in the bag-in-box packaging. The brand name creates trust and the availability of a variety of wines in bag-in-boxes could have a mere-exposure effect on consumers. As soon as the packaging is not perceived as risky either through the brand, the familiarity or the combination of those, consumers will buy wine in these packaging as well. These steps are similar to the very successful strategy of the Australian wine industry to introduce screw cap closures in the late 1990's (Mortensen and Marks, 2002): Well-known brands endorsed the 
screw cap closure, bottled parts of their harvest with this closure, and thereby, caused a lot of media attention.

Another possible strategy to reduce the perceived risk for consumers is offering the same wine in bottles and bag-in-box. According to Gourville (2006), producers and resellers partly have to accept that consumer resistance exits and need to manage it. Hence, the adoption takes time. With this strategy, consumers can slowly adopt the new packaging. For the consumers it becomes apparent that the wine itself has the same quality and the only difference between the two 'products' is the volume and the packaging. In addition to the awareness of the benefits of the packaging bag-in-box, consumers might be more open to this new type of packaging and would even re-buy wine in this packaging. This could be the basis for another study of consumers' attitude towards new types of packaging.

\subsection{Limitations}

Like every empirical research, this study also has limitations. First of all, the sample of the study was not representative but a convenience sample. This also explains the high percentage of students within the sample. Additionally, the questionnaire was conducted as a selfadministered online survey, which does not allow determining the sincerity of the answers. To address this issue, the individual time needed for the survey was reviewed and respondents with very low values were excluded from the analyses. Furthermore, the intention to buy as an indicator is quite established but as all intentions, it does not reflect the actual behaviour. Thus, the results should be interpreted with caution. Additionally, although wine is an experience good, the survey could not feature actual experiences, thus only virtual presentations of the products were possible. This lack of realism was counteracted by using photographs. However, this method cannot convey the same validity as a 'hands-on' presentation of the packaging. Finally, the information text for bag-in-box included convenience benefits as well as environmental benefits. Hence, more environmentally friendly participants could have focused on these benefits and the effect would not have been present without this information.

\subsection{Recommendations for future research}

There are various ways to pursue the results of this study in order to gain further insights about consumer behaviour and innovative packaging. Firstly, a large-scale representative study could overcome the limitations regarding the sample composition. Additionally, to address the issue of wine as an experience good, a sensory study could provide viable insights. In fact, a research setup in which consumers taste the same wine poured out of different packaging would reveal the unconscious perception of quality that is related to the packaging. This would also tackle the issue of the purely digital representation of the packaging in this study. Since wine is a product often consumed in company, the wine packaging could also have an influence on social recognition and is often dependent on the situation (e.g Hirche and Bruwer, 2014; Quester and Smart, 1998). Thus, these factors could be considered when looking at innovative packaging. Moreover, the general perception of innovativeness of packaging and the added value from the 
consumers' point of view would add to the body of innovation knowledge. Lastly, future research could also consider the perspective of producers on new packaging options and their adoption barriers for innovative packaging. 


\section{References}

Atkin, T., Garcia, R. and Lockshin, L. (2006), "A Multinational Study of the Diffusion of a Discontinuous Innovation”, Australasian Marketing Journal, Elsevier, Vol. 14 No. 2, pp. 17-33.

Atkin, T. and Newton, S. (2012), "Consumer awareness and quality perceptions: a case for Sonoma County wines”, Journal of Wine Research, Vol. 23 No. 2, pp. 155-171.

Barber, N. and Almanza, B. (2006), “Influence of Wine Packaging on Consumers’ Decision to Purchase”, Journal of Foodservice Business Research, Vol. 9 No. 4, pp. 83-98.

Barber, N., Almanza, B. and Dodd, T. (2008), "Relationship of Wine Consumers' SelfConfidence, Product Involvement, and Packaging Cues”, Journal of Foodservice Business Research, Vol. 11 No. 1, pp. 45-64.

Barber, N.A., Taylor, C. and Dodd, T. (2008), “Twisting Tradition: Consumers' Behavior Toward Alternative Closures”, Journal of Food Products Marketing, Vol. 15 No. 1, pp. 80-103.

Bearden, W.O. and Shimp, T.A. (1982), "The Use of Extrinsic Cues to Facilitate Product Adoption”, Journal of Marketing Research, Vol. 19 No. 2, pp. 229-239.

Bruwer, J. and Buller, C. (2013), "Product involvement, brand loyalty, and country-of-origin brand preferences of Japanese wine consumers”, Journal of Wine Research, Vol. 24 No. 1, pp. 38-58.

Celhay, F. and Passebois, J. (2011), "Wine labelling: is it time to break with tradition? A study of the moderating role of perceived risk", International Journal of Wine Business Research, Vol. 23 No. 4, pp. 318-337.

Cohen, J. (1992), “Statistical Power Analysis”, Current Directions in Psychological Science, Vol. 1 No. 3, pp. 98-101.

Delre, S.A., Jager, W., Bijmolt, T.H.A. and Janssen, M.A. (2007), "Targeting and timing promotional activities: An agent-based model for the takeoff of new products”, Journal of Business Research, Vol. 60, pp. 826-835.

DWI. (2016), “Deutscher Wein Statistik 2016/2017”, Deutsches Weininstitut GmbH, Bodenheim.

Famularo, B., Bruwer, J. and Li, E. (2010), "Region of origin as choice factor: wine knowledge and wine tourism involvement influence", International Journal of Wine Business Research, Vol. 22 No. 4, pp. 362-385.

Fernandes Ferreira Madureira, T.C. and Simões de Sousa Nunes, F.J. (2013), "Relevant attributes of Portuguese wines: matching regions and consumer's involvement level”, International Journal of Wine Business Research, Vol. 25 No. 1, pp. 75-86.

Gourville, J.T. (2006), “Eager Sellers and Stony Buyers”, Harvard Business Review, Vol. 84 No. 6, pp. 98-106.

Hauser, J., Tellis, G.J. and Griffin, A. (2006), "Research on Innovation: A Review and Agenda for Marketing Science”, Marketing Science, Vol. 25 No. 6, pp. 687-717.

Hayes, A.F. (2013), Introduction to mediation, moderation, and conditional process analysis, The Guilford Press, New York, doi:978-1-60918-230-4. 
Hirche, M. and Bruwer, J. (2014), "Buying a Product for an Anticipated Consumption Situation - Observation of High and Low Involved Wine Buyers in a Retail Store”, International Journal of Wine Business Research, Emerald, Vol. 26 No. 4, pp. 295-318.

Hollebeek, L.D. and Brodie, R.J. (2009), "Wine service marketing, value co-creation and involvement: research issues”, International Journal of Wine Business Research, Vol. 21 No. 4, pp. 339-353.

Hollebeek, L.D., Jaeger, S.R., Brodie, R.J. and Balemi, A. (2007), "The influence of involvement on purchase intention for new world wine”, Food Quality and Preference, Vol. 18 No. 8, pp. 1033-1049.

International Organisation of Vine and Wine. (2013), "World Customs Organization approves the proposal of the OIV: Wine in containers from 2 to 10 liters will not be considered as bulk wine", International Organisation of Vine and Wine, available at: http://www.oiv.int/oiv/info/envrac13 (accessed 7 August 2014).

International Organisation of Vine and Wine. (2016), "Weltkonjunkturbericht”, Organisation Internationale de la Vigne et du Vin, Paris.

Kumar, M. and Noble, C.H. (2015), "Beyond form and function: Why do consumers value product design?”, Journal of Business Research, Elsevier Inc., Vol. 69 No. 2, pp. 613620.

Laukkanen, T., Sinkkonen, S., Kivijärvi, M. and Laukkanen, P. (2007), "Innovation resistance among mature consumers”, Journal of Consumer Marketing, Vol. 24 No. 7, pp. 419-427.

Lockshin, L. and Corsi, A.M. (2012), “Consumer behaviour for wine 2.0: A review since 2003 and future directions”, Wine Economics and Policy, Vol. 1 No. 1, pp. 2-23.

Lockshin, L. and Spawton, T. (2001), "Using Involvement and Brand Equity to Develop a Wine Tourism Strategy”, International Journal of Wine Marketing, Vol. 13 No. 1, pp. 72-81.

Ma, Z., Yang, Z. and Mourali, M. (2014), “Consumer Adoption of New Products: Independent Versus Interdependent Self-Perspectives”, Journal of Marketing, Vol. 78 No. 2, pp. 101117.

McDaniel, C. and Baker, R.C. (1977), "Convenience Food Packaging and the Perception of Product Quality”, Journal of Marketing, Vol. 41 No. 4, pp. 57-58.

Mortensen, W. and Marks, B. (2002), “An Innovation in the Wine Closure Industry: Screw Caps Threaten the Dominance of Cork", Victoria University School of Management Working Paper Series, Vol. 18, pp. 2-14.

Murray, W. and Lockshin, L.S. (1997), "Consumer Acceptance of Synthetic Corks", International Journal of Wine Marketing, Vol. 9 No. 1, pp. 31-52.

Narayanan, S., Manchanda, P. and Chintagunta, P.K. (2005), “Temporal Differences in the Role of Marketing Communication in New Product Categories”, Journal of Marketing Research, Vol. 42 No. 3, pp. 278-290.

Orth, U.R. and Malkewitz, K. (2008), "Holistic Package Design and Consumer Brand Impressions”, Journal of Marketing, Vol. 72 No. 3, pp. 64-81.

Prendergast, G.P., Tsang, A.S.L. and Chan, C.N.W. (2010), "The interactive influence of country of origin of brand and product involvement on purchase intention", Journal of Consumer Marketing, Vol. 27 No. 2, pp. 180-188. 
Quester, P.G. and Smart, J. (1998), "The influence of consumption situation and product involvement over consumers' use of product attribute”, Journal of Consumer Marketing, Vol. 15 No. 3, pp. 220-238.

Rahman, I. and Reynolds, D. (2015), “Wine: Intrinsic attributes and consumers' drinking frequency, experience, and involvement”, International Journal of Hospitality Management, Elsevier Ltd, Vol. 44, pp. 1-11.

Ram, S. and Sheth, J.N. (1989), “Consumer Resistance to Innovations: The Marketing Problem and its solutions”, Journal of Consumer Marketing, MCB UP Ltd, Vol. 6 No. 2, pp. 5-14.

Rigaux-Bricmont, B. (1982), "Influences of brand name and packaging on perceived quality”, Advances in Consumer Research, Vol. 9 No. 1, pp. 472-477.

Rogers, E.M. (1976), “New Product Adoption and Diffusion”, Journal of Consumer Research, Vol. 2 No. March, pp. 290-301.

Rogers, E.M. (2003), Diffusion of Innovations, The Free Press, New York, 5thed.

Santini, C., Cavicchi, A. and Rocchi, B. (2007), "Italian wineries and strategic options: the role of Premium Bag in Box”, International Journal of Wine Business Research, Vol. 19 No. 3, pp. 216-230.

Sherman, S. and Tuten, T. (2011), "Message on a bottle: the wine label's influence", International Journal of Wine Business Research, Vol. 23 No. 3, pp. 221-234.

Spielmann, N. (2012), “Terroir? That's not how I would describe it”, International Journal of Wine Business Research, Vol. 24 No. 4, pp. 254-270.

Spiller, S.A., Fitzsimons, G.J., Lynch, J.G. and McClelland, G.H. (2013), "Spotlights, Floodlights, and the Magic Number Zero: Simple Effects Tests in Moderated Regression”, Journal of Marketing Research, Vol. 50 No. April, pp. 277-288.

Timmor, Y. and Katz-Navon, T. (2008), "Being the same and different: A model explaining new product adoption”, Journal of Consumer Behaviour, Vol. 7 No. 3, pp. 249-262.

Veale, R. (2008), "Sensing or knowing?: Investigating the influence of knowledge and selfconfidence on consumer beliefs regarding the effect of extrinsic cues on wine quality", International Journal of Wine Business Research, Vol. 20 No. 4, pp. 352-366.

Wells, L.E., Farley, H. and Armstrong, G.A. (2007), “The importance of packaging design for own-label food brands”, International Journal of Retail \& Distribution Management, Vol. 35 No. 9, pp. 677-690.

Zaichkowsky, J.L. (1988), “Involvement and the Price Cue”, Advances in Consumer Research, Vol. 15 No. 1, pp. 323-327.

Zaichkowsky, J.L. (1994), "The Personal Involvement Inventory: Reduction, Revision, and Application to Advertising”, Journal of Advertising, Vol. 23 No. 4, pp. 59-70.

A shorter version of this paper was awarded with the 'Second Runner-up Paper Award' at the 9th Conference of the Academy of Wine Business Research (AWBR).

The personal contribution to this article is above $80 \%$. 


\section{What about the environment? A choice-based conjoint study about wine}

Lucas Nesselhauf, Ruth Fleuchaus and Ludwig Theuvsen

This article is under review in a similar version for the International Journal of Wine Business Research therefore an online publication is currently not possible.

A shorter version of this article was accepted at the 10th Conference of the Academy of Wine Business Research (AWBR) Sonoma State University, July 25 - 28, 2017 


\section{The role of environmental information for wine innovation adoption - The case of fungus resistant grape varieties}

Lucas Nesselhauf, Ruth Fleuchaus and Ludwig Theuvsen

This article is accepted in a similar version for the

Proceedings of the 11th Conference of the Academy of Wine Business Research (AWBR) 


\begin{abstract}
Fungus resistant grape varieties (in the following FRGVs) as eco-innovation in the wine industry could be the key to a significantly lower use of fungicides and, therefore, to sustainable wine growing. The purpose of this paper is to examine the link between information about the environmental benefits of FRGVs and the purchase probability. This study is based on an online survey among 1,500 German wine consumers. The results show that the information increase the purchase probability. The information is particularly relevant for women, young and environmentally conscious consumers. Therefore, environmentally conscious consumers are a first target group for the diffusion of FRGVs. Moreover, the results show that more involved consumers tend to be more open to buy FRGV wines. The paper shows that information about the environmental benefits can accelerate the adoption of FRGVs as eco-innovation and that their target group of green-minded consumers might be best approached in organic grocery stores.
\end{abstract}




\section{Introduction}

Wine is deeply embedded in the European culture. Therefore, it is not surprising that about 60 per cent of the global wine production comes from Europe (Deutsches Weininstitut, 2017). Nevertheless, only seven per cent of the European farmland is used for wine growing. Alarmingly, 70 per cent of all fungicides used in Europe are used for grapes (Eurostat, 2000). These figures clearly show that the wine industry needs to find new, innovative solutions to reduce the amount of fungicides used in vineyards.

Fungus resistant grape varieties (FRGVs, in German: PIWIs) could be a part of the solution. FRGVs have one significant benefit compared to common grape varieties: they need fewer fungicides. Due to natural (not genetically modified) cross-breeding of fungus resistant varieties with European grape varieties, the FRGVs have developed a natural resistance against powdery and downy mildew. This natural resistance allows wine growers to reduce the amount of fungicides by around 70 to 80 per cent (Pedneault and Provost, 2016).

The FRGVs' environmental benefit is undoubted, however, only around 2.5 per cent of the German wine-growing area is planted with FRGVs (Statistisches Bundesamt, 2016). So far, wine growers do no plant FRGVs on a large scale because they doubt the commercial success of FRGVs. These grape varieties have new names and a different, yet pleasing taste. The biggest issue for wine growers is that consumers are currently not aware of FRGVs (Pedneault and Provost, 2016). Thus, consumers do not actively look for these varieties while purchasing wine.

Since FRGVs can be seen as an eco-innovation in the wine industry, the question arises whether it is possible to accelerate the diffusion of these innovative grape varieties. This paper seeks to answer this question and tries to identify target groups for wines made from FRGVs. The aim of this study is to characterize possible early adopters and the early majority adopting FRGVs regarding their attitudes and their socio-demographics. Therefore, an online survey among 1,500 German wine consumers was conducted to investigate whether information about the environmental benefits of FRGVs can serve as a means to promote the adoption of FRGVs among consumers.

Beginning with a literature review about innovation adoption, environmentalism and involvement, the paper leads to the hypotheses and the methodology section. This is followed by the results and the managerial implications drawn from this study. At last, the conclusion with limitations and recommendations for further research is drawn to top this paper off.

\section{Literature review and problem studied}

The relevant literature for this study stems from three different fields of research. First, the following section examines the literature on innovations and the influence of information on the adoption process. The second part sheds light on the link between environmentalism and wine. The last section of the literature review focuses on the wine product involvement which 
is widely used to analyse consumer behaviour. In addition, the section connects FRGVs with the extant literature in the three research areas. So far, there is no literature approaching the subject of the marketing of FRGVs and how these varieties can be promoted to consumers, which is one of the gaps in existing research that this paper attempts to fill.

\subsection{Innovation and information}

Innovations of all kinds are a widely discussed topic among academics and practitioners (Fagerberg et al., 2012; Karakaya et al., 2014; Peres et al., 2010; Rogers, 2003). However, innovations face one main problem: the diffusion. Diffusion describes the process of spreading new products and services among individuals. Typically, individuals adopting innovations are characterised in different groups depending on how early they adopt the innovation: innovators, early adopters, early and late majority, and laggards. In the diffusion of innovations, the innovators adopt the new product or service first, followed by the other groups mentioned above. The laggards are the last group to adopt the innovation (Rogers, 2003).

Ram and Sheth (1989) explain why consumers are hesitant to adopt beneficial innovations. The authors identify five main barriers that innovations need to overcome: (1) value barriers, (2) usage barriers, (3) risk barriers, (4) tradition barriers, and (5) image barriers. The first three barriers are classified as 'functional barriers' and the last two as 'psychological barriers'. The tradition barrier is particularly relevant for new foods and beverages. Therefore, the authors state that changing food consumption habits is a possibly long and difficult route. Educating consumers about the benefits of the new product, understanding and respecting the consumers' habits is the strategy to overcome the tradition barrier (Ram and Sheth, 1989). Based on that insight, Atkin, Garcia and Lockshin (2006) use the theory of innovation barriers to examine the adoption of screw cap closures in three different countries and confirm Ram and Sheth's (1989) findings. Information about the advantages of the innovations fosters the diffusion; the information can be spread among the consumers via educational advertisements as well as through word-of-mouth marketing (Atkin et al., 2006).

According to Rogers (2003), a product or an idea needs to appear to be new to an individual in order to be described as an innovation. Following Rogers' (2003) definition, FRGVs meet this requirement, so these grape varieties can be considered to be an innovation. Furthermore, the environmental advantages of FRGVs classify this innovation as an eco-innovation according to Karakaya et al. (2014). Adopting FRGVs from a consumer's perspective implies trying a new grape variety with a possibly new and unknown flavour profile. Opting for FRGV wines also means that the production of this wine is less harmful for the environment than wines made of traditional grape varieties. Most consumers, however, are not aware of this fact and have not yet come across wines produced with FRGVs. This information might be able to overcome the aforementioned tradition barrier. Thus, educating consumers could speed up the diffusion of FRGVs. 


\subsection{Environmentalism and wine}

The environmental advantages of FRGVs entail the link to green-minded consumers. So far, however, no study examines the link between environmentalism and the consumers' attitude towards FRGVs. Furthermore, apart from quality and taste perception studies, FRGVs have not been the topic of consumer or marketing studies so far (Pedneault and Provost, 2016). Generally speaking, organic and sustainable wines only gained attention in the course of the past decade. While Lockshin and Corsi (2012) ascribe organic and sustainable wine a small consumer segment, Schäufele and Hamm (2017) see more potential in this segment, partly due to policy changes. Hence, academia also shifted their focus on consumers of sustainable and organic wine. Many studies examine the price premium for environmentally friendly wines (Sellers, 2016; Sogari et al., 2016; Vecchio, 2013) and the influence of labels on consumer behaviour (Loureiro, 2003; Pomarici and Vecchio, 2014; Sogari et al., 2015).

Only few studies investigate the link between consumers' environmentalism and the consumption of sustainable and organic wine. D'Amico et al. (2016) suggest that consumers with more environmental concerns tend to pay higher price premiums for organic wine. Furthermore, Barber et al. (2009) show that environmental involvement increases the objective environmental wine knowledge, which in turn increases the attitude towards sustainable wine and the purchase probability.

\subsection{Wine product involvement}

The concept of the product involvement describes an individual's perceived relevance of a product category or even a product in general (Zaichkowsky, 1986). The product involvement has proven to be of great value for the analysis of wine purchase behaviour and the segmentation of wine consumers (Barber et al., 2007; Hirche and Bruwer, 2014; Lockshin et al., 2001; Taylor et al., 2018). Consumers focus on different wine product attributes depending on their level of involvement (Barber et al., 2007; Hirche and Bruwer, 2014; Zaichkowsky, 1988). The price cue is of lower interest for consumers with higher levels of involvement (Barber et al., 2007; Zaichkowsky, 1988). Moreover, consumers with a high involvement in wine tend to lay more weight to the origin of the wine (Quester and Smart, 1998), place more importance on the vintage, the grape variety and the brand (Hirche and Bruwer, 2014), and consume more wine than their lower involved counterparts (Hirche and Bruwer, 2014).

Barber et al. (2009) examine the relationship between wine product involvement, environmental involvement, subjective and objective environmental wine knowledge. The results suggest that the main precedent of objective environmental wine knowledge is the environmental involvement. Their study shows that a higher wine product involvement does not necessarily mean that the consumers are aware of environmental issues within the product category. 
The review of the literature about innovation adoption, information, environmentalism and involvement regarding wine suggests that there is a research gap that this paper seeks to fill. As Pedneault and Provost (2016) state, the commercialisation of FRGVs needs to be part of further research. The question that this study will answer is whether information about the environmental benefits of FRGVs can foster the adoption of these varieties. And if so, what are the socio-demographics and the attitudes of those people who are willing to purchase these varieties. As shown in the literature review, especially the wine product involvement and the environmentalism could lead to more insights regarding the adoption process. The next section will develop hypotheses in order to analyse these questions.

\section{Hypotheses}

Based on the extant literature about information about and in the context of innovations, the first hypothesis is as follows:

$\mathrm{H}_{1}$ : The information about the environmental advantages of FRGVs influences the purchase probability positively.

The information about the FRGVs serves as a means to overcome the tradition barrier as suggested by Ram and Sheth (1989). The educating text helps consumers to identify the link between these specific grape varieties and the environmental consequences of wine growing and consumption.

The following hypotheses concern the initial purchase probability. Hence, the participants have not been aware of the information about the FRGVs' benefits for the environment so far. Therefore, these hypotheses consider the participants' involvement and their current knowledge about these varieties.

$\mathrm{H}_{2}$ : The initial purchase probability increases with an increasing level of wine product involvement.

$\mathrm{H}_{3}$ : The initial purchase probability increases with an increasing number of individually known FRGVs.

The reasoning for $\mathrm{H}_{2}$ is mainly that more involved participants might have a more thorough expertise about wine in general and could thus be more receptive to new and unknown varieties. Moreover, the name 'fungus resistant' might be easier to understand for more involved participants.

Furthermore, it is reasonable to assume that consumers' environmentalism would influence the initial purchase probability as well. Participants who are more environmentally aware would possibly be informed about FRGVs and therefore, the fourth hypothesis is as follows:

$\mathrm{H}_{4}$ : The initial purchase probability increases with an increasing level of environmentalism. 
$\mathrm{H}_{8}$ : The information about FRGVs is more important for women than for men.

Because the literature on organic wine and the age of consumers is not conclusive, the age of the participants will be analysed within the regression analysis, but is not part of any of the hypotheses. Figure 1 visualizes the eight hypotheses with all variables and the respective scale

\section{Research methodology and dataset}

The basis for this study is an online survey among 1,500 German wine consumers. The participants of the survey were selected with a quota sampling method within an online access panel. The quota for age and gender were obtained from the "b4p - best for planning” data about the wine drinking population in Germany. Another screening parameter for the participants of the survey was their wine consumption. All participants consume wine at least once per month.

After the screening questions, the participants were asked about the grape varieties they know. First, each participant had to select whether they prefer red or white wines, and accordingly they were shown a list of 20 grape varieties. Ten of these grape varieties were the most common grape varieties in Germany, such as Riesling and Chardonnay or Pinot Noir and Merlot. The remaining ten grape varieties were FRGVs that are available in Germany, such as Cabernet Blanc and Regent. The number of FRGVs that the participant knows is reflected in the variable FRGV $V_{\text {known. }}$ Consequently, the variable $\mathrm{FRGV}_{\text {known }}$ can range between zero and ten. The frequencies for this variable can be found in Table 1.

Table 1: Frequencies of FRGV known

\begin{tabular}{l|c|c|c|c|c|c|c|c|c|c|c}
\hline FRGV known & $\mathbf{0}$ & $\mathbf{1}$ & $\mathbf{2}$ & $\mathbf{3}$ & $\mathbf{4}$ & $\mathbf{5}$ & $\mathbf{6}$ & $\mathbf{7}$ & $\mathbf{8}$ & $\mathbf{9}$ & \multicolumn{1}{|c}{$\mathbf{1 0}$} \\
\hline $\mathrm{N}(1,500)$ & 765 & 446 & 128 & 64 & 35 & 25 & 10 & 11 & 4 & 8 & 4 \\
\hline \multicolumn{8}{c}{ Std }
\end{tabular}

Mean: $0.96 \quad$ Std. Deviation: 1.537

The main items for this study are the questions about the purchase probability for wines made of FRGVs in combination with an information text about FRGVs for consumers. First, the participants were asked "Would you buy wines made of strong, fungus resistant grape varieties given that the price is acceptable?” (5-point rating scale from 'yes, sure' to 'no, certainly not'). Hence, the first question is labelled as 'initial purchase probability’ (IPP). This first question

Figure 2: Survey and variable design
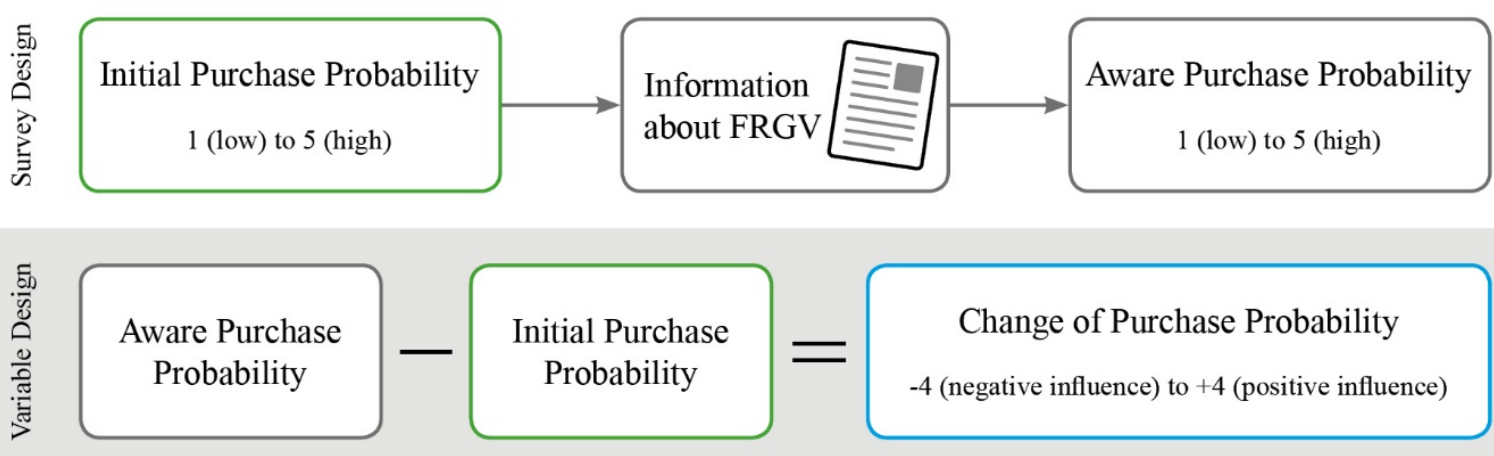
Regarding the change of purchase probability, it is arguable that the number of known FRGVs does not come into play. Whether participants know many FRGVs or only a few is not relevant for the influence of the information provided.

$\mathrm{H}_{5}$ : The influence of the information about FRGVs is independent from the number of individually known FRGVs.

Following Barber et al. (2009), the wine product involvement would have no influence on the actual knowledge about the environmental issues. Therefore, the information about the FRGVs' benefits would influence more involved participants in the same way as less involved participants.

$\mathrm{H}_{6}$ : The influence of the information about FRGVs is independent from the level of involvement.

Based on the results from D'Amico et al. (2016), the relationship between the information about the FRGVs' environmental benefits and the participants' environmentalism is supposed to be positive. Therefore, the seventh hypothesis is as follows:

$\mathrm{H}_{7}$ : The influence of the information about FRGVs is more important to participants with higher levels of environmentalism.

At last, the literature shows that gender plays a role in analysing the consumer behaviour regarding organic and environmentally friendly wines (Schäufele and Hamm, 2017). Women tend to consume more organic wine (Mann et al., 2012). Since the information about the environmental benefits of FRGVs are not present in the elicitation of the initial purchase probability, the following hypothesis only relates to the change of purchase probability.

Figure 1: Model design and visualisation of hypotheses

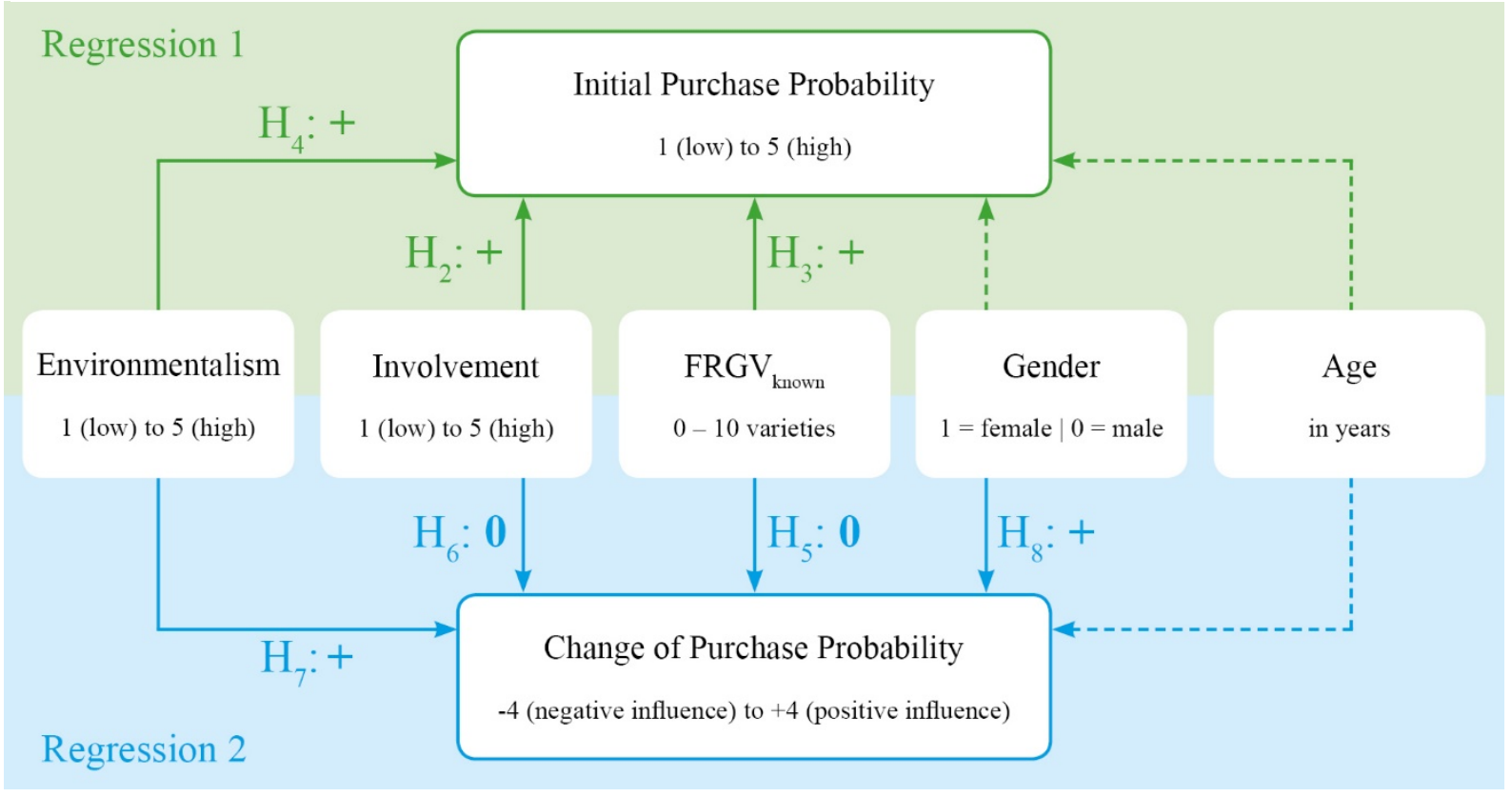


was followed by the information text about FRGVs for consumers. Third, the first question was asked again to measure the difference that is attributable to the information text. This second question is labelled as 'aware purchase probability' (APP). As a further variable, the 'change of purchase probability’ (CPP) was calculated by subtracting the IPP from the APP. Figure 2 shows the survey design and the variable design of the CPP.

The information about FRGV focus on the environmental advantages while avoiding the defamation of traditional grape varieties. For the survey, the name 'PIWI' was avoided and replaced by 'strong grape varieties'. The information consisted of the following text, originally formulated in German:

\begin{abstract}
Strong grape varieties for a strong environment
Strong for the environment - Strong grape varieties are fungus resistant by nature and therefore, need fewer fungicides: the pollution from chemical pesticides can be reduced for plants, animals and humans.

Strong through fewer carbon emissions - Since fewer fungicides need to be sprayed with tractors, the carbon emissions - and obviously costs - can be reduced. Furthermore, the reduced demand for fungicides would lead to a lower production of fungicides. This also reduces the carbon emissions.

Strong through natural breeding - Strong, fungus resistant grape varieties are the result of cross breeding of European grape varieties and American or Asian wild grape varieties. Strong grape varieties are e.g. Cabernet Blanc and Souvignier Gris (whites), Cabernet Cortis and Monarch (reds).

Strong for wine growing on every slope - Steep slopes are part of the tradition and the culture of winegrowing. The cultivation on extremely steep slopes is effortful and expensive. Thanks to the reduced amount of fungicides for strong grape varieties, less manual labour and effort is necessary.
\end{abstract}

As construct for the involvement in the product category wine, Hirche and Bruwer's (2014) wine product involvement construct was chosen. The construct combines ten items about wine consumption and wine related behaviour. Table 2 lists the ten items of the construct.

Table 2: Wine product Involvement construct by Hirche \& Bruwer (2014)

- I have good general knowledge about wine. - Every now and then I visit a wine seminar.

- Other people often ask me advice regarding - Sometimes, when drinking wine, I like the wine. intellectual challenge of complex tastes.

- Wine offers me relaxation and fun when life's pressures build up.

- I am or would consider getting a member in a wine club.

- I take particular pleasure from wine. $\quad$ - I regularly attend wine events / festivals.

- I very much enjoy spending time in a wine - Every now and then I participate at a wine shop. $\quad$ tasting.

All items on a 5-point Likert scale $\quad$ Cronbach's $\alpha: 0.875$

The nine items for the environmentalism construct (see Table 3) originate from the feasibility study by Scholl et al. (2016). Their feasibility study for an environmentalism construct in Germany listed many items with regard to the behaviour and the attitude towards 
environmentalism. Due to the limited scope of this study's online survey, these nine items were selected to cover the environmentalism as good as possible. The nine items focus on actual consumption of organic food and sustainable products, and concerns about a sustainable lifestyle.

Table 3: Environmentalism construct adapted from Scholl et al. (2016)

-It worries me when I think about the environment, in which our children and

-A functioning and natural environment is necessarily a part of a good life.* grandchildren will probably live.*

-In Germany, the protection of the

-We all have to cut back on our lifestyle to protect our natural basis of existence.* -I often engage in social and ecological issues.*

-I pay attention to the sustainability of products (ecology, durability, fair working conditions).*

-Within the last four weeks, how often did environment should be the first priority, even you choose to buy organic food / though it could mean less economic growth.* beverages?**

-We can solve our environmental problems by changing our economic system and our lifestyle.*
-Within the last two years, how often did you choose to buy environmentally friendly clothes?**

The analysis of the sample and the following calculations were carried out with IBM SPSS Statistics 24. The sample of 1,500 German wine consumers is composed of 57.4 per cent female and 42.6 per cent male participants. The distribution of the age within the sample is as follows: (1) up to 29 years: 7.9 per cent; (2) 30-39 years: 10.2 per cent; (3) 40-49 years: 15.1 per cent; (4) 50-59 years: 17.1 per cent; (5) 60-69 years: 36.1 per cent; and (6) over 70 years: 13.7 per cent.

Table 4: Environmentalism and involvement within the sample

\begin{tabular}{l|c|c|c|r|c}
\hline Construct & 1 to 1.99 & 2 to 2.99 & 3 to 3.99 & \multicolumn{1}{|c}{4 to 5} & Total \\
\hline Environmentalism & $43(2.9 \%)$ & $239(15.9 \%)$ & $739(49.3 \%)$ & $479(31.9 \%)$ & 1,500 \\
Involvement & $230(15.3 \%)$ & $683(45.5 \%)$ & $478(31.9 \%)$ & $109(7.3 \%)$ & 1,500 \\
\hline
\end{tabular}

The constructs for environmentalism and involvement show sufficient variation within the sample. Table 4 shows the distribution in four classes for both constructs. The attitude towards environmentalism is rather positive (mean: 3.56; median: 3.67; std. deviation: 0.74). On average, the sample reflects a medium involvement (mean: 2.76; median: 2.70; std. deviation: 0.77). The majority of the sample lies between 2 and 2.99 on the 5 -point Likert scale.

The eight hypotheses will be analysed with the above mentioned constructs and variables. The following results section looks at each hypothesis separately after presenting the sample composition. The results section leads to a discussion of the results, which is followed by the implications. 


\section{Results}

To analyse hypothesis $\mathrm{H}_{1}$, the influence of an information about FRGVs on the purchase probability, a paired t-test with the variables IPP and APP, was carried out. The results (Table 5) show a significant positive change $[t(1499)=17.054, p<0.000]$. Therefore, the data clearly supports $\mathrm{H}_{1}$. Due to the within subject design and the close proximity of the questions and the information, it can be assumed that the participants, who changed their rating, did not know about the environmental advantages of FRGVs.

Table 5: Paired t-test for the influence of the information

\begin{tabular}{c|r|r|r|r|r}
\hline Mean & Std. Deviation & Std. Error Mean & t & df & Sig. \\
\hline 0.326 & 0.740 & 0.019 & 17.054 & 1,499 & 0.000 \\
\hline
\end{tabular}

The analysis of the hypotheses $\mathrm{H}_{2}, \mathrm{H}_{3}$ and $\mathrm{H}_{4}$ is based on a regression analysis of the variable $I P P$ as dependent variable and the variables Environmentalism, Involvement, FRGV $V_{\text {known }}$, Age, and Gender as independent variables. Table 6 shows the results of the regression analysis in detail. The $\mathrm{R}^{2}$ of the model is 0.047 and the Cohen's effect size is 0.221 , which stands for a small to medium effect size (Field, 2005).

Table 6: Results of the first regression analysis - IPP

\begin{tabular}{|c|c|c|c|c|c|}
\hline $\mathrm{R}$ & $\mathrm{R}^{2}$ & Adjusted $\mathrm{R}^{2}$ & $\begin{array}{l}\text { Std. Error of } \\
\text { the Estimate }\end{array}$ & $\begin{array}{l}\text { Durbin- } \\
\text { Watson }\end{array}$ & $\begin{array}{c}\text { Cohen's } \\
\text { Effect Size }\end{array}$ \\
\hline \multirow[t]{3}{*}{0.216} & 0.047 & 0.043 & 0.787 & 2.017 & 0.221 \\
\hline & \multicolumn{2}{|c|}{$\begin{array}{l}\text { Unstandardized } \\
\text { Coefficients }\end{array}$} & \multirow{2}{*}{$\begin{array}{c}\text { Standardized } \\
\text { Coefficients } \\
\text { Beta }\end{array}$} & \multirow[b]{2}{*}{$\mathrm{t}$} & \multirow[b]{2}{*}{ Sig. } \\
\hline & $\mathrm{B}$ & Std. Error & & & \\
\hline Constant & 2.912 & 0.140 & & 20.865 & 0.000 \\
\hline Environmentalism & 0.019 & 0.029 & 0.017 & 0.643 & 0.520 \\
\hline Involvement & 0.165 & 0.029 & 0.157 & 5.639 & 0.000 \\
\hline FRGV $V_{\text {known }}$ & 0.032 & 0.014 & 0.061 & 2.275 & 0.023 \\
\hline Age & 0.004 & 0.001 & 0.067 & 2.504 & 0.012 \\
\hline Gender ( $f=1$ ) & -0.099 & 0.043 & -0.061 & -2.289 & 0.022 \\
\hline
\end{tabular}

The data supports hypotheses $\mathrm{H}_{2}$ and $\mathrm{H}_{3}$. The variables Involvement and FRGV known are significant to an $\alpha$-level of 0.05 . The IPP increases with an increasing level of involvement, therefore, the highly involved participants are more open to purchasing wines made of FRGVs. As expected, the more FRGVs a participant knows, the higher the IPP. The variable Environmentalism is not significant ( $\mathrm{p}>0.05$ ), hence $\mathrm{H}_{4}$ cannot be supported. The level of environmental awareness does not influence the IPP. The variables Age and Gender are significant $(\mathrm{p}<0.05)$. According to the data, the IPP increases with increasing age. Furthermore, men tend to have a higher IPP than women.

The regression to analyse the hypotheses $\mathrm{H}_{5}, \mathrm{H}_{6}, \mathrm{H}_{7}$ and $\mathrm{H}_{8}$ is set up with the $\mathrm{CPP}$ as dependent variable and the five variables Environmentalism, Involvement, $F R G V_{\text {known }}$, Age and Gender as 
independent variables. The CPP reflects the change in purchase probability that is attributable to the information about FRGVs. Table 7 displays the results of the regression analysis. The $\mathrm{R}^{2}$ of the model is 0.038 and the Cohen's effect size of 0.199 state a small effect (Field, 2005).

As hypothesized, the number of individually known FRGVs does not change the influence of the information provided. The variable $F R G V_{\text {known }}$ is not significant ( $\mathrm{p}>0.05$ ). Thus, the data clearly supports $\mathrm{H}_{5}$. Moreover, the data supports $\mathrm{H}_{6}$, since Involvement is also not significant ( $p>0.05$ ). This means that no matter how involved the participants are, the influence of information about FRGVs does not depend on it. In other words, the text has the same influence for participants with low and high involvement.

However, participants that show a high environmental awareness, reflected by high values of Environmentalism, react more positively to the information about the environmental benefits of FRGVs. The effect of Environmentalism is significant $(\mathrm{p}<0.00)$. This was hypothesized in $\mathrm{H}_{7}$ and therefore, the data supports this hypothesis. Furthermore, the Gender variable is significant $(p<0.00)$ and positive. Hence, women tend to value the information on FRGVs more than men. Consequently, the data supports $\mathrm{H}_{8}$. In this regression analysis, Age is also significant $(p<0.00)$. However, the coefficient is negative. Therefore, the data shows that the influence of the text is greater on younger participants.

Table 7: Results of the second regression analysis - CPP

\begin{tabular}{|c|c|c|c|c|c|}
\hline $\mathrm{R}$ & $\mathrm{R}^{2}$ & Adjusted R² & $\begin{array}{l}\text { Std. Error of } \\
\text { the Estimate }\end{array}$ & $\begin{array}{l}\text { Durbin- } \\
\text { Watson }\end{array}$ & $\begin{array}{c}\text { Cohen's } \\
\text { Effect Size }\end{array}$ \\
\hline \multirow[t]{3}{*}{0.195} & 0.038 & 0.035 & 0.727 & 1.931 & 0.199 \\
\hline & \multicolumn{2}{|c|}{$\begin{array}{c}\text { Unstandardized } \\
\text { Coefficients }\end{array}$} & \multirow{2}{*}{$\begin{array}{c}\text { Standardized } \\
\text { Coefficients } \\
\text { Beta } \\
\end{array}$} & \multirow[b]{2}{*}{$\mathrm{t}$} & \multirow[b]{2}{*}{ Sig. } \\
\hline & $\mathrm{B}$ & Std. Error & & & \\
\hline Constant & 0.097 & 0.129 & & 0.750 & 0.454 \\
\hline Environmentalism & 0.133 & 0.027 & 0.132 & 4.922 & 0.000 \\
\hline Involvement & -0.027 & 0.027 & -0.028 & -0.993 & 0.321 \\
\hline FRGV known & -0.003 & 0.013 & -0.007 & -0.248 & 0.804 \\
\hline Age & -0.004 & 0.001 & -0.088 & -3.279 & 0.001 \\
\hline Gender $(\mathrm{f}=1)$ & 0.133 & 0.040 & 0.089 & 3.330 & 0.001 \\
\hline
\end{tabular}

To test for multicollinearity, the variance inflation factors for the regression analyses for model 1 and 2 were calculated. For both regression models, the variance inflation factors are between 1.114 and 1.210 . These results mean that multicollinearity can be ruled out in both regressions (Field, 2005).

In conclusion, the IPP is already quite high with an average value of 3.61 on a 5-point Likert scale. This means that the participants of this study are already fairly open to purchase wines made from FRGVs. Another look at the regression on IPP clearly reveals that highly involved, more mature, male participants have the highest purchase probability. In addition, prior 
knowledge of FRGVs fosters the purchase probability as well, suggesting that the consumption or at least the knowledge of FRGV wines is a positive factor.

Turning to the information about the environmental benefits of FRGVs, the results show that the information provided increases the purchase probability significantly. This suggests that information regarding the environmental benefits is relevant for the participants of this study. On average, the information can lift the purchase probability by 0.326 points on a 5-point scale. The analysis of the second regression analysis gives an insight into the attitudes and sociodemographics of the participants who are particularly responsive to the information on FRGVs. Participants who show more environmental awareness are more responsive to the information. Furthermore, younger participants and females are particularly open to the information. Whether participants are explicitly involved in the product category wine or not does not come into play when it comes down to the environmental information about the FRGVs.

\section{Discussion}

The fact that information about the environmentally friendly production of FRGV wines increases the purchase probability is consistent with other studies, such as Wiedmann et al. (2014) and Ay et al. (2014), that looked at the influence of information regarding organic wine. Mann et al. (2012) also state that more knowledge about organic production increases the purchase probability for organic wines.

This study also finds that the information about the environmentally friendly production is more relevant for women. Hence, the environmental benefits of FRGVs are more important for women. This finding is in line with the literature of Barber et al. (2010) and Mann et al. (2012), that show that women tend to value sustainability claims more than men.

As Barber et al. (2009) state that involvement in a product category does not necessarily lead to more knowledge about environmental issues in this category, this study confirms those results. Involvement is not relevant for the effect of information about environmental benefits of FRGVs. Whether the participants have high involvement in wine or not, the information about the environmental advantages of FRGVs have the same effect.

In summary, the results are consistent with the extant literature. Furthermore, the results indicate that the diffusion of FRGVs can be supported by information about their environmental benefits. How these results can translate into practical implications is part of the following section.

\section{Practical managerial implications and recommendations}

Since the results show that information can foster the adoption of FRGVs, the first practical implication regarding FRGVs is somehow simple: inform consumers about the environmental benefits of FRGVs. In order to reach those consumers that are most responsive to the 
information, younger and environmentally aware consumers should be focused on first. It is reasonable to assume that environmentally aware consumers tend to shop at least sometimes in organic stores (see Table 3, item 8 and 9). Thus, these stores could be a first place to approach consumers with information about FRGVs and also wines made from FRGVs on the shelf. However, regular supermarkets might also be a place to introduce FRGV wines to consumers as long as the wines and the information is somewhere close to other organic or sustainable products to reach the environmentally aware consumers.

The influence of information about the environmental benefits of FRGVs is not dependent on the consumers' wine product involvement. However, consumers with a higher level of involvement tend to have a higher initial purchase probability for FRGV wines. Since high involvement consumers tend to buy wine more often in dedicated wine shops (Nesselhauf et al., 2017), these shops could also be part of a distribution strategy. There, the information about the environmental benefits would be of less importance.

Furthermore, marketing of new products is also dependent on the abilities of the individual firms. A well-structured marketing campaign for FRGV wines can foster the diffusion among a firm's consumers. The marketing messages can target different consumers groups, such as women, millennials or environmentally aware consumers.

At last, the reduction of fungicides in the wine industry could also be seen as an issue for regulation. Quota schemes for wine growers could be imaginable to gain market share for FRGVs and force the producer to market these varieties to consumers.

\section{Conclusions}

The eco-innovation FRGVs has the potential to reduce the wine industry's environmental harm. The industry could promote these grape varieties to show its sustainable thinking and act as role model for further agricultural industries. Consumers are open to this eco-innovation. Especially the consumers with higher levels of involvement state a relatively high initial purchase probability for wines made of FRGVs.

Providing information about the environmental benefits of FRGVs supports the diffusion of FRGVs. The information enables consumers to see the advantages of these grape varieties. Even though the environmental advantages will not suffice to change the consumers' behaviour completely, it may be an additional factor to try wines made from FRGVs.

Looking at the influence of information about the FRGVs and the consumer group that is most responsive to it, it becomes obvious that the information is most effective for consumers with higher levels of environmentalism. This clearly shows that consumers who care for the environment are more open to information about products that reduce the harm for the environment. Thus, environmentally aware consumers can be seen as the first target group for 
wines made from FRGVs. The data further suggests that women and younger consumers tend to be more convinced by the information.

As every study, also this research has limitations. First of all, the purchase probability was elicited with direct questions about a hypothetical situation. Schäufele and Hamm (2018) show that the attitude-behaviour gap for wine consumers is low, however, the social desirability in this context should not be underestimated. Furthermore, the price cue in the purchase probability questions was left out on purpose to eliminate price effects. However, it obstructs statements about the willingness to pay. Moreover, the sample is not representative for the German wine consuming population. Online access panels and quota sampling do not lead to a strictly representative sample. However, the sample size and the structure of the sample allow a conservative generalization.

In order to overcome some of those limitations, further research could combine attitudinal data and actual purchase behaviour of FRGV wines. Furthermore, in order to address the relatively low explained variance in this study, it is necessary to take into account that wine purchase is a very complex purchasing process. Further studies could widen the aspects that are part of the surveys, hence narrow the gap between the hypothetical and the actual situation. Another addition for this research would be to investigate the specific parts of the text and analyse the influence of each section to gain more insights in the consumers' minds. So far, the text was only examined as a whole and not in its specific parts.

The findings of this study may also be important for further eco-innovations. There are many product categories and products that are stuck in early phases of the diffusion, such as insects as food. Products that have mainly altruistic environmental benefits might face similar problems within the society. Therefore, the scope of this research could be widened and further studies could be multifaceted. 


\section{References}

Atkin, T., Garcia, R. and Lockshin, L. (2006), "A Multinational Study of the Diffusion of a Discontinuous Innovation”, Australasian Marketing Journal, Elsevier, Vol. 14 No. 2, pp. 17-33.

Ay, J., Chakir, R. and Marette, S. (2014), "Does living close to a vineyard increase the willingness-to-pay for organic and local wine?", EAAE 2014 Congress 'Agri-Food and Rural Innovations for Healthier Societies', pp. 1-35.

Barber, N., Ismail, J. and Dodd, T. (2007), "Purchase Attributes of Wine Consumers with Low Involvement”, Journal of Food Products Marketing, Vol. 14 No. 1, pp. 69-86.

Barber, N., Taylor, C. and Strick, S. (2009), “Wine consumers' environmental knowledge and attitudes: Influence on willingness to purchase", International Journal of Wine Research, Vol. 1 No. 1, p. 59.

Barber, N., Taylor, D.C. and Strick, S. (2010), "Selective marketing to environmentally concerned wine consumers: a case for location, gender and age", Journal of Consumer Marketing, Vol. 27 No. 1, pp. 64-75.

D’Amico, M., Di Vita, G. and Monaco, L. (2016), "Exploring environmental consciousness and consumer preferences for organic wines without sulfites", Journal of Cleaner Production, Elsevier Ltd, Vol. 120, pp. 64-71.

Deutsches Weininstitut. (2017), “Deutscher Wein Statistik 2017 / 2018”, Deutsches Weininstitut GmbH, Bodenheim.

Eurostat. (2000), Pflanzenschutz in der EU - Einsatz von Pflanzenschutzmitteln in der Europäischen Union: Daten 1992-1996, (Statistical Office of the European Communities (EUROSTAT),Ed.), Office for Offical Publications of the European Communities, Luxemburg, 1sted., available at: http://ec.europa.eu/eurostat/documents/3217494/562673 5/KS-34-00-302-3A-EN.PDF/de96ec49-f486-4bde-bbd8-95c6ddb74cee?version=1.0.

Fagerberg, J., Fosaas, M. and Sapprasert, K. (2012), "Innovation: Exploring the knowledge base”, Research Policy, Elsevier B.V., Vol. 41 No. 7, pp. 1132-1153.

Field, A. (2005), Discovering Statistics Using SPSS, SAGE Publications Ltd, London, 2nded.

Hirche, M. and Bruwer, J. (2014), "Buying a Product for an Anticipated Consumption Situation - Observation of High and Low Involved Wine Buyers in a Retail Store”, International Journal of Wine Business Research, Emerald, Vol. 26 No. 4, pp. 295-318.

Karakaya, E., Hidalgo, A. and Nuur, C. (2014), "Diffusion of eco-innovations: A review", Renewable and Sustainable Energy Reviews, Vol. 33, pp. 392-399.

Lockshin, L. and Corsi, A.M. (2012), “Consumer behaviour for wine 2.0: A review since 2003 and future directions”, Wine Economics and Policy, Vol. 1 No. 1, pp. 2-23.

Lockshin, L., Quester, P. and Spawton, T. (2001), "Segmentation by Involvement or Nationality for Global Retailing: A Cross-national Comparative Study of Wine Shopping Behaviours”, Journal of Wine Research, Vol. 12 No. 3, pp. 223-236.

Loureiro, M.L. (2003), "Rethinking new wines: Implications of local and environmentally friendly labels”, Food Policy, Vol. 28 No. 5-6, pp. 547-560.

Mann, S., Ferjani, A. and Reissig, L. (2012), “What matters to consumers of organic wine?”, British Food Journal, Vol. 114 No. 2, pp. 272-284. 
Nesselhauf, L., Deker, J.S. and Fleuchaus, R. (2017), "Information and involvement: the influence on the acceptance of innovative wine packaging”, International Journal of Wine Business Research, Vol. 29 No. 3, pp. 285-298.

Pedneault, K. and Provost, C. (2016), "Fungus resistant grape varieties as a suitable alternative for organic wine production: Benefits, limits, and challenges”, Scientia Horticulturae, Elsevier B.V., doi:10.1016/j.scienta.2016.03.016.

Peres, R., Muller, E. and Mahajan, V. (2010), “Innovation diffusion and new product growth models: A critical review and research directions", International Journal of Research in Marketing, Elsevier B.V., Vol. 27 No. 2, pp. 91-106.

Pomarici, E. and Vecchio, R. (2014), “Millennial generation attitudes to sustainable wine: an exploratory study on Italian consumers", Journal of Cleaner Production, Elsevier Ltd, Vol. 66, pp. 537-545.

Quester, P.G. and Smart, J. (1998), "The influence of consumption situation and product involvement over consumers' use of product attribute”, Journal of Consumer Marketing, Vol. 15 No. 3, pp. 220-238.

Ram, S. and Sheth, J.N. (1989), “Consumer Resistance to Innovations: The Marketing Problem and its solutions”, Journal of Consumer Marketing, MCB UP Ltd, Vol. 6 No. 2, pp. 5-14.

Rogers, E.M. (2003), Diffusion of Innovations, The Free Press, New York, 5thed.

Schäufele, I. and Hamm, U. (2017), “Consumers” perceptions, preferences and willingness-topay for wine with sustainability characteristics: A review”, Journal of Cleaner Production, Vol. 147, pp. 379-394.

Schäufele, I. and Hamm, U. (2018), "Organic wine purchase behaviour in Germany: Exploring the attitude-behaviour-gap with data from a household panel”, Food Quality and Preference, Elsevier, Vol. 63 No. July 2017, pp. 1-11.

Scholl, G., Gossen, M., Holzhauer, B. and Schipperges, M. (2016), Mit welchen Kenngrößen kann Umweltbewusstsein heute erfasst werden? Eine Machbarkeitsstudie, TEXTE 58/2016, Dessau-Roßlau.

Sellers, R. (2016), "Would you Pay a Price Premium for a Sustainable Wine? The Voice of the Spanish Consumer”, Agriculture and Agricultural Science Procedia, Elsevier Srl, Vol. 8, pp. 10-16.

Sogari, G., Corbo, C., Macconi, M., Menozzi, D. and Mora, C. (2015), “Consumer attitude towards sustainable-labelled wine: an exploratory approach”, International Journal of Wine Business Research, Vol. 27 No. 4, pp. 312-328.

Sogari, G., Mora, C. and Menozzi, D. (2016), "Factors driving sustainable choice: the case of wine”, British Food Journal, Vol. 118 No. 3, pp. 632-646.

Statistisches Bundesamt. (2016), “Grunderhebung der Rebflächen”, Fachserie 3, R 3.1.5, 2015, Statistisches Bundesamt, Wiesbaden.

Taylor, J.J., Bing, M., Reynolds, D., Davison, K. and Ruetzler, T. (2018), "Motivation and personal involvement leading to wine consumption ", International Journal of Contemporary Hospitality Management, Vol. 30 No. 2, pp. 702-719.

Vecchio, R. (2013), “Determinants of willingness-to-pay for sustainable wine: Evidence from experimental auctions”, Wine Economics and Policy, Elsevier, Vol. 2 No. 2, pp. 85-92. 
Wiedmann, K.-P., Hennigs, N., Henrik Behrens, S. and Klarmann, C. (2014), “Tasting green: an experimental design for investigating consumer perception of organic wine”, British Food Journal, Vol. 116 No. 2, pp. 197-211.

Zaichkowsky, J.L. (1986), “Conceptualizing involvement”, Journal of Advertising, Vol. 15 No. 2, pp. 4-34.

Zaichkowsky, J.L. (1988), "Involvement and the Price Cue”, Advances in consumer research, Vol. 15 No. 1, pp. 323-327. 


\section{Conclusions and outlook}

The purpose of this dissertation is the identification of factors to accelerate the diffusion of innovations in the product category wine. Therefore, innovative packaging solutions and fungus resistant grape varieties (FRGVs) have been chosen to test the consumer acceptance and the influence of information about these innovations. The three articles also include the concept of wine involvement to cover the consumers' attitude towards wine.

The article 'Information and involvement: The influence on the acceptance of innovative wine packaging' examines the relationship between degree of innovativeness, information about the innovation, involvement and the consumer acceptance. The article suggests that information about the benefits of an innovative packaging effectively supports overcoming adoption barriers. This result is in line with Atkin et al. (2006). The moderated regression analysis reveals that particularly low involvement participants benefit from information about the advantages of an innovative packaging. The diverging effect of a product cue for consumers with low and high involvement confirms many other studies that show diverging utilization of product cues (Bruwer et al., 2017; Pomarici et al., 2017; Spielmann and GélinasChebat, 2012). The survey also includes the place of purchase with the consideration of involvement. Since low involvement participants tend to buy wine more often in supermarkets, they should especially be targeted with information about the benefits of packaging. The varying preferred places of purchase dependent on the level of involvement show that wine involvement is a justified parameter to segment wine consumers, and hereby confirm extant literature (Bruwer et al., 2017; Hirche and Bruwer, 2014; Lockshin et al., 2001; Quester and Smart, 1998).

The second article in this dissertation 'What about the environment? A choice-based conjoint study about wine' unveils the importance of product attributes that are related to FRGVs. The choice experiment with 1,500 participants elicits the preference structure for these six tested attributes: (1) 'reduction of pesticides', (2) 'reduction of carbon emissions', (3) 'familiarity with the grape variety', (4) 'organic certification', (5) the slogan 'better for the environment', and (6) 'price'. The article answers the question whether new grape varieties can overcome 
adoption barriers by having environmental benefits. The analysis shows that consumers ascribe the highest importance to 'price'. The price is typically the most important factor (Lockshin et al., 2006; Mueller et al., 2010; Quester and Smart, 1998). The second most important attribute is the 'familiarity with the grape variety'. However, 'reduction of pesticides' and 'reduction of carbon emissions' are the attributes that are both directly related to the environmental benefits of FRGVs, and which can outweigh an unfamiliar grape variety. Hence, the communication of the environmental benefits of FRGVs can support overcoming adoption barriers. Such a communication strategy of educating consumers can be particularly helpful for the tradition barriers that are prevalent in this case (Atkin et al., 2006; Ram and Sheth, 1989). Furthermore, a cluster analysis based on the participants' preferences results in a three cluster solution. The first cluster, the green-minded, can be characterized by their preference for the 'reduction of pesticides'. Around one third of the sample belongs to the green-minded cluster. The traditionalists represent the second cluster. The cluster's name aims at the traditional wine consumption behaviour in Germany that wine is sold and chosen by variety. This cluster's participants particularly value the familiarity of the grape variety. The third cluster, the price-minded consumers, reflect the group that mainly focuses on the price. They ascribe little importance to the remaining attributes. Confirming extant studies (e.g. Pomarici et al., 2017), the price focused cluster has the lowest average level of involvement. Furthermore, the green-minded cluster has the highest average level of environmentalism. Schäufele and Hamm (2018) state that the attitude-behaviour-gap for environmentally conscious wine consumers is very narrow, meaning environmentally aware wine consumers tend to buy wine that is environmentally friendly produced. The results of this article show a coherence between the level of environmentalism and the preference structure of the choice experiment, and thus confirm Schäufele and Hamm (2018).

The third article 'The role of environmental information for wine innovation adoption - The case of fungus resistant grape varieties' builds on the results of the previous article. Since the environmental benefits of FRGVs are relevant at least for some consumers, the within-subject design of this article examines the effect of environmental information on the purchase probability. The study uses two regression models to identify consumer groups that are open to FRGVs or open to the information about the benefits of FRGVs. The initial purchase probability reflects the general openness to FRGVs, possibly even without exactly knowing what FRGVs are. In this case, the more involved participants show a higher purchase probability. Furthermore, the knowledge of FRGVs influences the purchase probability positively. Hence, participants that are already familiar with FRGVs are also open to buy such a wine. The participants' environmentalism does not show a significant effect on the initial purchase probability. After information about the environmental benefits of FRGVs, the participants were asked the same question regarding their purchase probability for FRGV wines. The regression analysis reveals that the participants' environmentalism comes into play when the participants are aware of the FRGVs' benefits. The influence of the information 
about the benefits is stronger for environmentally conscious participants. In this regression analysis, the participants' involvement level is not significant. The results are in line with Barber et al. (2009) that wine involvement does not lead to more knowledge about environmental issues of wine production. Therefore, whether the participants are involved in wine or not does not make a difference for the effect of the information. In general, the article shows that information about the benefits of FRGVs enhances the purchase probability. So, the first and the third article clearly state that information about the benefits of innovations accelerates the diffusion and confirm extant studies (for instance, Atkin et al., 2006; Ram and Sheth, 1989).

The results of these three articles show that information about innovations helps overcoming adoption barriers. These results also have implications for practice. In the case of packaging solutions, the benefits could be directly on the packaging. Consumers would instantly know how the packaging could solve an everyday problem. Furthermore, an innovative packaging could also lead to differentiation as in the case of StackWine. The very different packaging and the benefits make the product stand out of the masses and help to attract specific target groups. Obviously, producers and retailers need to support new packaging with information to reduce the risk for consumers. Having big brands introducing new packaging solutions and lending their trustworthy name to an innovation would reduce the risk as well. Due to the correlation of place of purchase and wine involvement, producers and retailers can use that information to tailor their communication strategies according to their needs. In supermarkets and discounters, the producers should provide information on the packaging. In wine shops, the personnel should know about the benefits of an innovative packaging and promote these features accordingly.

The supporting effect of information is also present for the FRGVs as the results of the second and the third article show. The communication of the FRGVs' environmental benefits can be a vital factor for the adoption of FRGVs for environmentally conscious consumers. Producers and retailers should not be afraid of talking about the benefits of these new grape varieties. Consumers might need a reason to particularly try this new wine instead of any other wine on the shelf. The highly competitive market and the complexity of the product category wine forces consumers to follow heuristics. These heuristics might lead to a familiar grape variety produced by a familiar winery. They might ask why they should try this unknown wine. The information about the environmental benefits might just be that reason. Curiosity and the knowledge that the production of this wine is more environmentally friendly could be a reason to choose something unknown. This will not lead to consumers that only drink wines from FRGVs, but it would help to accelerate the diffusion of these varieties, which in turn leads to a reduction of pesticides and a reduction of carbon emissions. This results in a more sustainable wine industry, in the ecological and economic sense. In addition, the producers should possibly look for consumers that are more environmentally conscious. These consumers might be found in supermarkets with a large choice of organic products and 
dedicated organic supermarkets. Furthermore, the education of sales personnel in all kinds of retailers with customer consultants could lead to an acceleration of the diffusion.

Apart from implications for practice, the results point to implications for further research. As the three articles show, the concept of involvement proves useful for the segmentation of wine consumers. This result confirms other studies on wine consumer behaviour and involvement (Bruwer et al., 2017; Hirche and Bruwer, 2014; Lockshin et al., 2001). Furthermore, the level of involvement and the place of purchase for wine can be useful for further studies on involvement and consumer behaviour.

Additionally, the environmentalism construct seems to be reliable to identify wine consumers that value environmentally friendly wine production. Future research could build on that result to gain more insights into the consumer behaviour of environmentally conscious consumers. Research about environmentalism and the information about environmental benefits could be extended to further product categories. Adapting the model to other food products such as coffee, tea or even innovative new food categories such as algae or insects seems plausible. Furthermore, it is arguable to extend the model to other, non-food product categories and services. For example, innovative mobility solutions, such as car sharing, or environmentally friendly produced clothing could be further applications to explore the relationship between environmentalism and purchase intentions or actual purchases. Moreover, the information about the environmental benefits should be further examined. The information could be divided into different values and analysed separately. The influence of the different aspects of environmental benefits would lead to more knowledge about the consumers' motivation. The purchase of environmentally friendly produced food is motivated by altruistic and egoistic motives (Kareklas et al., 2014). Applying these findings to the wine industry with its peculiarities would lead to more insights into the purchase decisions for environmentally friendly wine.

The relatively low importance of the organic certification in comparison to the reduction of pesticides and of carbon emissions raises further questions for academia. The organic certification might be too complex for consumers and the simpler statement of a reduction of pesticides or carbon emissions might be easier to understand. The motivation of organic and sustainable purchases are an important topic in the literature (De Dominicis et al., 2017; Kareklas et al., 2014; Schäufele and Hamm, 2017; Yadav, 2016). However, the question whether simpler statements would more effectively drive the adoption of sustainable products has not been answered so far. Furthermore, the organic label induces a halo effect that improves sensory ratings and hedonic liking (Apaolaza et al., 2017). Comparing the organic label with a wine that states the reduction of pesticides and carbon emissions would lead to additional information on the consumers' perceptions of these attributes.

The importance of the reduction of pesticides points to the question whether the results can be generalized for other food products. The awareness of pesticides in combination with the 
importance of their reduction could lead to more insights into the consumers' minds. Since wine is a very complex product with many attributes, the reduction of pesticides is one amongst many others. For commodities such as flour or sugar, the environmentally friendly production could be a valuable differentiation. However, further studies need to examine the importance of such environmental claims for consumers.

This dissertation's limitations indicate further necessary research. First, the research for this dissertation has been conducted in Germany. Therefore, the results mainly apply to the German consumers within these studies. The wine market with its peculiarities, such as the country-of-origin effects (Okechuku, 1994) and other differences between countries (Cohen and Sirieix, 2009; Mueller et al., 2011), demands cross-cultural studies to enable the generalization. Moreover, the sampling method influences the generalizability of findings. For these three articles, the convenience and quota sampling method were chosen. Both methods do not lead to a strictly representative sample. However, the sample sizes are respectable and sufficient for the statistical tests.

Another limitation of studies with online surveys with consumers is the hypothetical situation. The participants do not need to spend their money for the products they choose. Therefore, the answers might be biased. The attitude-behaviour gap could be particularly present for the questions regarding products that are more environmentally friendly due to a social desirability effect (Aschemann-Witzel and Niebuhr Aagaard, 2014; Aschemann-Witzel and Zielke, 2017; Schäufele and Hamm, 2017). For the product category wine, however, the proenvironmental consumers also tend to buy sustainable wine (Schäufele and Hamm, 2018). Hence, it can be assumed that the attitude-behaviour gap is relatively low in the articles at hand. To further improve the validity of the choice experiment, cheap talk was presented to the participants. Cheap talk constitutes an introductory text about the hypothetical situation and the consequences of untrue answers, such as false interpretation of the results. Cheap talk enhances the validity and lets the participant focus on the tasks (Carlsson et al., 2005).

Overcoming these limitations could be possible by conducting subsequent studies in real life markets. The analysis of actual purchase data in supermarkets or wineries accompanied by attitude surveys could lead to more insights into the consumer behaviour regarding new grape varieties and innovative packaging. In case of unavailability of actual purchase data, sensory tests could serve as an alternative. An experiment with consumers, who state the hedonic liking of wines with an FRGV label and a traditional grape variety, could add to the knowledge about the consumer behaviour. Similar experiments could be conducted with different types of packaging.

In conclusion, the results of the dissertation at hand support practitioners interested in marketing wines from FRGVs and introducing new packaging solutions. In the competitive German wine market, wine growers and retailers need to look for ways to differentiate and show consumers their unique range of products. By adopting these innovations, wine growers 
can adapt to this need. In combination with educating consumers and giving additional information about these innovative products, wine growers and retailers can increase the acceptance among consumers. For consumers, the information about the FRGVs' environmental benefits and the more convenient packaging solutions are relevant and improve the perception of these innovations. Furthermore, these FRGVs allow wine growers to protect the environment while adapting to the new challenges of the climate change. Research institutes in Europe breed new varieties to support wine growers with varieties that meet the requirements of consumers and the environment (Eads, 2018). Meanwhile, wine growers need to face the adoption barriers of consumers and to use information to reduce these barriers. In the long run, wine growers will be able to adopt FRGVs and use innovative packaging solutions to protect the environment, reduce costs and satisfy consumers. 


\section{References}

Apaolaza, V., Hartmann, P., Echebarria, C. and Barrutia, J.M. (2017), “Organic label’s halo effect on sensory and hedonic experience of wine: A pilot study", Journal of Sensory Studies, Vol. 32 No. 1, pp. 1-11.

Aschemann-Witzel, J. and Niebuhr Aagaard, E.M. (2014), "Elaborating on the attitudebehaviour gap regarding organic products: Young Danish consumers and in-store food choice”, International Journal of Consumer Studies, Vol. 38 No. 5, pp. 550-558.

Aschemann-Witzel, J. and Zielke, S. (2017), “Can’t Buy Me Green? A Review of Consumer Perceptions of and Behavior Toward the Price of Organic Food”, Journal of Consumer Affairs, Vol. 51 No. 1, pp. 211-251.

Atkin, T., Garcia, R. and Lockshin, L. (2006), “A Multinational Study of the Diffusion of a Discontinuous Innovation”, Australasian Marketing Journal, Elsevier, Vol. 14 No. 2, pp. 17-33.

Barber, N., Taylor, C. and Strick, S. (2009), “Wine consumers’ environmental knowledge and attitudes: Influence on willingness to purchase”, International Journal of Wine Research, Vol. 1 No. 1, p. 59.

Bruwer, J., Chrysochou, P. and Lesschaeve, I. (2017), "Consumer involvement and knowledge influence on wine choice cue utilisation”, British Food Journal, Vol. 119 No. 4, pp. 830-844.

Carlsson, F., Frykblom, P. and Lagerkvist, J.C. (2005), "Using cheap talk as a test of validity in choice experiments”, Economics Letters, Vol. 89 No. 2, pp. 147-152.

Cohen, E. and Sirieix, F. d'Hauteville and L. (2009), “A cross-cultural comparison of choice criteria for wine in restaurants", International Journal of Wine Business Research, Vol. 21 No. 1, pp. 50-63.

De Dominicis, S., Schultz, P.W. and Bonaiuto, M. (2017), "Protecting the environment for self-interested reasons: Altruism is not the only pathway to sustainability", Frontiers in Psychology, Vol. 8 No. JUN, pp. 1-13.

Eads, L. (2018), “Scientists engineer 'supergrapes' to combat fungal disease”, The Drinks Business, available at: https://www.thedrinksbusiness.com/2018/08/scientists-engineersupergrapes-to-combat-disease/ (accessed 13 August 2018).

Hirche, M. and Bruwer, J. (2014), "Buying a Product for an Anticipated Consumption Situation - Observation of High and Low Involved Wine Buyers in a Retail Store”, International Journal of Wine Business Research, Emerald, Vol. 26 No. 4, pp. 295-318.

Kareklas, I., Carlson, J.R. and Muehling, D.D. (2014), “'I eat organic for my benefit and yours': Egoistic and altruistic considerations for purchasing organic food and their implications for advertising strategists”, Journal of Advertising, Vol. 43 No. 1, pp. 1832.

Lockshin, L., Jarvis, W., d’Hauteville, F. and Perrouty, J.P. (2006), “Using simulations from discrete choice experiments to measure consumer sensitivity to brand, region, price, and awards in wine choice”, Food Quality and Preference, Vol. 17 No. 3-4, pp. 166-178.

Lockshin, L., Quester, P. and Spawton, T. (2001), "Segmentation by Involvement or Nationality for Global Retailing: A Cross-national Comparative Study of Wine Shopping Behaviours”, Journal of Wine Research, Vol. 12 No. 3, pp. 223-236.

Mueller, S., Lockshin, L., Saltman, Y. and Blanford, J. (2010), “Message on a bottle: The 
relative influence of wine back label information on wine choice”, Food Quality and Preference, Elsevier Ltd, Vol. 21 No. 1, pp. 22-32.

Mueller, S., Remaud, H. and Chabin, Y. (2011), "How strong and generalisable is the Generation Y effect? A cross-cultural study for wine”, International Journal of Wine Business Research, Vol. 23 No. 2, pp. 125-144.

Okechuku, C. (1994), “The Importance of Product Country of Origin”:, European Journal of Marketing, Vol. 28 No. 4, pp. 5-19.

Pomarici, E., Lerro, M., Chrysochou, P., Vecchio, R. and Krystallis, A. (2017), “One size does (obviously not) fit all: Using product attributes for wine market segmentation”, Wine Economics and Policy, Elsevier B.V., Vol. 6 No. 2, pp. 98-106.

Quester, P.G. and Smart, J. (1998), "The influence of consumption situation and product involvement over consumers' use of product attribute”, Journal of Consumer Marketing, Vol. 15 No. 3, pp. 220-238.

Ram, S. and Sheth, J.N. (1989), "Consumer Resistance to Innovations: The Marketing Problem and its solutions”, Journal of Consumer Marketing, MCB UP Ltd, Vol. 6 No. 2, pp. 5-14.

Schäufele, I. and Hamm, U. (2017), “Consumers’ perceptions, preferences and willingness-topay for wine with sustainability characteristics: A review”, Journal of Cleaner Production, Vol. 147, pp. 379-394.

Schäufele, I. and Hamm, U. (2018), "Organic wine purchase behaviour in Germany: Exploring the attitude-behaviour-gap with data from a household panel”, Food Quality and Preference, Elsevier, Vol. 63 No. July 2017, pp. 1-11.

Spielmann, N. and Gélinas-Chebat, C. (2012), "Terroir? That's not how I would describe it", International Journal of Wine Business Research, Vol. 24 No. 4, pp. 254-270.

Yadav, R. (2016), “Altruistic or egoistic: Which value promotes organic food consumption among young consumers? A study in the context of a developing nation”, Journal of Retailing and Consumer Services, Elsevier, Vol. 33, pp. 92-97. 


\section{Publications}

Peer-reviewed Paper Nesselhauf, Lucas, Johannes S. Deker, and Ruth Fleuchaus (2017), "Information and involvement: the influence on the acceptance of innovative wine packaging”, International Journal of Wine Business Research, Vol. 29 Issue: 3, pp. 285 - 298.

Conference Papers Nesselhauf, Lucas, Ruth Fleuchaus, and Ludwig Theuvsen (2019), "The role of environmental information for wine innovation adoption - The case of fungus resistant grape varieties”, Proceedings of the 11th Conference of the Academy of Wine Business Research (AWBR), ISBN 978-0-620-81006-7.

Nesselhauf, Lucas and Jana Heimel (2018), “Wine Cycling Tourism Who does that, and why?", 12th Annual AAWE Conference 2018. June 10 - 14, 2018, Cornell University, Ithaca, New York, USA.

Nesselhauf, Lucas, Ruth Fleuchaus, and Ludwig Theuvsen (2017), "German Wine Consumers and New Grape Varieties - A Choicebased Conjoint Analysis", 10th International Conference of the Academy of Wine Business Research. July 25 - 28, 2017, Sonoma State University, Rohnert Park, USA.

Nesselhauf, Lucas, Ruth Fleuchaus, and Ludwig Theuvsen (2017), "German Wine Consumers and New Grape Varieties - A Choicebased Conjoint Analysis”, 11th Annual AAWE Conference 2017. June 28 - July 2, 2017, University of Padova, Padua, Italy.

Nesselhauf, Lucas, Johannes Deker und Ruth Fleuchaus (2016), “Old wine in new bottles? The impact of information on the acceptance of innovative wine packaging", 9th Academy of Wine Business Research Conference. February 17 - 18, 2016, University of South Australia, Adelaide, Australia. 
Awards

Presentations
Conference Best Paper Award, 10th International Conference of the Academy of Wine Business Research. July 25 - 28, 2017, Sonoma State University, Rohnert Park, USA.

Second Runner-up Paper Award, 9th Academy of Wine Business Research Conference. February 17 - 18, 2016, University of South Australia, Adelaide, Australia.

Nesselhauf, Lucas (2018), "Vermarktungschancen pilzwiderstandsfähiger Rebsorten”, Bundesausschuss für Weinforschung - Jahrestagung, May 22 - 24, 2018, Staatliches Weinbauinstitut Freiburg, Freiburg im Breisgau.

Nesselhauf, Lucas (2018), “Weinmarketing bei PIWIs ein Sonderfall?”, Presentation at the 58. Arbeitstagung vom Forschungsring des Deutschen Weinbaus (FDW), April 10 - 11 2018, Weinsberg.

Fleuchaus, Ruth, Anna Heitlinger von der Emde and Lucas Nesselhauf (2016), "Weinbau mit Zukunft: Pilzwiderstandsfähige Rebsorten im Minimalschnitt im Spalier - Erste Ergebnisse zu sozioökonomischen Aspekten und Konsumentenverhalten”, Presentation at 56th Arbeitstagung vom Forschungsring des Deutschen Weinbaus (FDW), April 19 - 20, 2016, Bad Kreuznach.

Poster

Fleuchaus, Ruth and Lucas Nesselhauf (2018), "German Wine Consumers and New Grape Varieties - A Cluster Analysis”, PLANT 2030, February 05 - 07, 2018, Potsdam

Nesselhauf, Lucas, Ruth Fleuchaus and Ludwig Theuvsen (2017), “Bio-Siegel oder einfach nur „besser für die Umwelt”: Welchen Einfluss hat Zertifizierung?”, Jahrestagung der Schweizerischen Gesellschaft für Agrarwirtschaft und Agrarsoziologie, March 30 - 31, 2017, Chur, Switzerland.

Fleuchaus, Ruth and Lucas Nesselhauf (2017), "German Wine Consumers and New Grape Varieties - A Choice Experiment", PLANT 2030, February 20 - 22, 2017, Potsdam.

Fleuchaus, Ruth and Lucas Nesselhauf (2016), "Fungus Resistant Grape Varieties: Consumer Perception and Marketing”, PLANT 2030, March 14 - 16, 2016, Potsdam. 


\section{Declaration}

Name: Lucas Nesselhauf

Anschrift: Victoria-Wolff-Weg 5, 74072 Heilbronn

Ich beabsichtige, eine Dissertation zum Thema

Wine and Innovation - Consumer Acceptance of New Grape Varieties and Wine Packaging an der Georg-August-Universität Göttingen anzufertigen. Dabei werde ich von Herrn Prof. Dr. Ludwig Theuvsen betreut.

Ich gebe folgende Erklärung ab:

1. Die Gelegenheit zum vorliegenden Promotionsvorhaben ist mir nicht kommerziell vermittelt worden. Insbesondere habe ich keine Organisation eingeschaltet, die gegen Entgelt Betreuerinnen und Betreuer für die Anfertigung von Dissertationen sucht oder die mir obliegenden Pflichten hinsichtlich der Prüfungsleistungen für mich ganz oder teilweise erledigt.

2. Hilfe Dritter wurde bis jetzt und wird auch künftig nur in wissenschaftlich vertretbarem und prüfungsrechtlich zulässigem Ausmaß in Anspruch genommen. Insbesondere sind alle Teile der Dissertation selbst angefertigt; fremde Hilfe habe ich dazu weder unentgeltlich noch entgeltlich entgegengenommen und werde dies auch zukünftig so halten.

Des Weiteren ist mir bekannt, dass Unwahrhaftigkeiten hinsichtlich der vorstehenden Erklärung die Zulassung zur Promotion ausschließen bzw. später zum Verfahrensabbruch oder zur Rücknahme des erlangten Grades berechtigen. 


\section{Curriculum Vitae}

$\begin{array}{ll}\text { Name: } & \text { Lucas Nesselhauf } \\ \text { Date of birth: } & \text { 31 March } 1988 \\ \text { Place of birth: } & \text { Bad Säckingen } \\ \text { Marital status: } & \text { single } \\ \text { Nationality: } & \text { German }\end{array}$

Educational path

Since 05/2015

Research fellow, research project 'novisys'

Faculty of International Business, Hochschule Heilbronn

10/2015 - 12/2018 Promotionsstudiengang für Agrarwissenschaften in Göttingen

Georg-August-Universität Göttingen

09/2012 - 02/2015 Mannheim Master in Management (M.Sc.)

Universität Mannheim (1,7)

Focus: Marketing

$01-06 / 2014$

Semester abroad (ERASMUS), Reims, Frankreich

NEOMA Business School, Campus Reims

10/2009 - 09/2012 Betriebswirtschaftslehre (B.Sc.)

Westfälische Wilhelms-Universität, Münster $(1,9)$

10/2011 - 01/2012 Semester abroad (ERASMUS), York, GB

University of York, York Management School

Abitur, Grimmelshausen Gymnasium, Offenburg $(1,5)$ 


\section{Acknowledgement | Danksagung}

Neue Einsichten und Erkenntnisse, viel Freude, etwas Frustration, reichlich Abwechslung und intellektuellen Austausch: Das werde ich mit der Zeit verbinden, die ich in die Erarbeitung dieser Dissertation gesteckt habe. Das habe ich allerdings nicht alles allein geschafft. Ich konnte mich auf viele besondere Personen verlassen. Deshalb bleibt mir nur eines zu sagen: Danke.

Zuerst möchte ich mich bei Prof. Dr. Ruth Fleuchaus bedanken für die Betreuung in Heilbronn und die schöne, angenehme Zusammenarbeit. Bei Prof. Dr. Ludwig Theuvsen möchte ich mich für die Betreuung in Göttingen und für die freundliche Aufnahme in sein tolles Lehrstuhl-Team bedanken. Bei Anna Heitlinger von der Emde bedanke ich mich für die vielen Gelegenheiten zum Gedankenaustausch und die fortwährenden Ermutigungen.

Ohne die moralische Unterstützung meines Freundeskreises wären diese drei Jahre nicht so schön gewesen. Daher gilt auch ihnen mein Dank. Dabei möchte ich insbesondere Verena für die fehlerfreie Grammatik und die schönen Worte danken.

Bei Johanna bedanke ich mich für die unaufhörlichen Aufmunterungen und Ermutigungen, Abwechslung und Ablenkung zu gegebener Zeit, und vor allem für das Verständnis für geblockte Wochenenden, lange Abende und das ein oder andere Mal schlechte Laune. Danke!

Meiner Familie möchte ich danken für das Verständnis, dass ich nicht immer so viel Zeit hatte, wie es vielleicht nötig gewesen wäre. Bei meinen Großeltern möchte ich mich bedanken für den Zuspruch zu meinen Vorhaben. Iris möchte ich danken für die Ermutigungen und das Vertrauen in mich. Bei Armin möchte ich mich für die langjährige Unterstützung und den Blick auf das große Ganze bedanken. Und ganz besonders danke ich meiner Mama Martina: Danke für alles. 